\title{
What We Know about Mobilizing College Students to Vote
}

\author{
Elizabeth A. Bennion \\ Department of Political Science \\ Indiana University South Bend \\ David W. Nickerson \\ Department of Political Science \\ Temple University
}

\begin{abstract}
This paper introduces readers to the political science literature on voter mobilization, highlighting what we know (and what we wish we knew) about getting college students to vote in the United States. The purpose of the paper is to provide advice to those wishing to mobilize student voters and to help set a research agenda for the future. We focus on experiments designed to test the effectiveness of specific techniques to register and engage young voters, documenting practical steps that have proven effective across campuses. While only $40 \%$ of $18-24$ year olds are enrolled in college, and turnout is lower for non-college youth, college students represent a population that academics should be best positioned to mobilize and turn into voters.
\end{abstract}

Revised version of a paper prepared for the Data-Driven Strategies to Promote Youth Turnout workshop at the Massachusetts Institute of Technology, August 29, 2018. (Uploaded 10.31.19) 
This paper introduces readers to the political science literature on youth voter mobilization, highlighting what we know (and what we wish we knew) about getting college students to vote in the United States. While only $40 \%$ of 18-24 year olds are enrolled in college, and turnout is lower for non-college youth, college students represent a population that academics should be best positioned to mobilize and turn into voters.

\section{Purpose}

The purpose of this paper is to provide evidence-based advice to groups seeking to boost turnout on U.S. college campuses. Non-profit organizations, both on campus and off, often rely on past practice, anecdotal evidence, or creative ideas when planning voter outreach activities. While these tactics might be effective, their efficacy is not guaranteed and organizers have no principled way of determining which tactics are successful and which ones fell flat. This paper provides a review of the scientific literature based on randomized field experiments designed to test the effectiveness of specific techniques to register, educate, and engage young voters. The emphasis is on practical steps that have proven effective across campuses and can be taken utilized by diverse campus leaders.

\section{Significance}

Younger generations (i.e. generation X, Millennials and post-Millennials) make up a majority of voting-eligible adults in the United States, but they do not yet cast the majority of votes despite this numerical advantage. ${ }^{1}$ This gap in turnout is not a new phenomenon; turnout rates among younger people have consistently been lower than older citizens since the Census Department began tracking voter turnout on the Current Population Survey November Supplement. Members of the current generation are not only less likely to participate in midterm elections than their older contemporaries, but turnout rates of Millennials and Gen Xers is lower than older generations when they were the same age. ${ }^{2}$ Such non-participation by young voters does not bode well for the future, as voting is habit forming ${ }^{3}$ and aging is no guarantee of higher turnout. $^{4}$

The potential electoral clout of the youngest voters becomes clear when the raw numbers are tallied. As of April 2018 (the most recent data available), 59\% of adults who are eligible to vote are Gen Xers, Millennials or "post-Millennials." 5 In the 2014 midterm election, which had a historically low turnout, these younger generations accounted for $53 \%$ of eligible voters but cast just 36 million votes, which is 21 million fewer votes than the Boomer, Silent, and Greatest generations, who are ages 54 and older in 2018. Since 2014, the number of voting-eligible Gen Xers, Millennials, and post-Millennials has increased by 18 million. Naturalization accounts for some of this increase, but most of the growth is attributed to the 15 million post-Millennials (18 to 21 years old) who are now voting age. This latter group is focus of this paper. Meanwhile, there are now 10 million fewer eligible voters among the Boomer and older generations than there were in $2014,{ }^{6}$ so the potential electoral clout of the youngest voters has grown, but increasing voter turnout among younger voters is needed to realize this power. 
There are two primary reasons that it is important to study the best ways to mobilize young voters. The first reason is normative. It is important for a representative democracy to reflect all segments of the population. When groups of voters fail to participate in the electoral process, their voices are unrepresented when selecting political leaders and undervalued when creating public policy. To the extent that groups systematically participate in elections at lesser rates - whether through barriers to entry or a choice to abstain - our representative democracy will be less representative.

This normative goal is especially important for college campuses. One of the primary purposes of higher education is to educate citizens for democracy. ${ }^{7}$ Both Thomas Jefferson and Benjamin Franklin articulated the importance of an educated citizenry for securing a democracy. ${ }^{8}$ If students opt out of politics, colleges and universities are failing to achieve the public purpose and civic mission of higher education.

This gap in participation across generations creates an electorate that does not represent the views of the entire body politic. Not only are Millennials the most diverse generation in U.S. history, but the gap in policy preferences between younger and older generations is now as wide as is has been in decades. ${ }^{9}$ On average, millennials express more liberal views about racial discrimination, immigration, gun control, and the power of diplomacy in international relations. ${ }^{10}$ While post-Millennial attitudes about racial diversity, religion, and culture make them more likely than previous generations to support Democrats, their focus on individual rights and comfort with digital platforms (including national security apparatuses) make them amenable to key planks in the Republican Party platform. Regardless of their voting preferences, a fully representative electorate requires that Millennial voices be heard at the ballot box and colleges have an affirmative duty to increase turnout.

The second reason mobilization of college students is import to study is that the question poses an interesting empirical challenge. Young voters are highly mobile, which makes contacting and engaging them in the political process more difficult. They do not have strong ties to political parties, which reduces their contact with organizations that traditionally mobilize voters. They also do not have a track record of participating, because they have been eligible for very few years, which makes predicting electoral behaviors much more difficult. As such, the study of young voters presents an empirical challenge not found in older citizens. Moreover, the sheer numbers of young voters make them an empirically important group to study. The United States has one of the lowest voting rates in the developed world. ${ }^{11}$ With 20 million potential voters in college, raising the college voting rate by 15 percentage points (which they did recently at Northwestern University) would produce three million more voters. ${ }^{12}$ Thus, young voters constitute an import voting bloc in their own right and understanding how best to engage them is important to understand the future of U.S. politics.

\section{What We Know about Mobilizing College Students to Vote}

As we summarize what we know about the best ways to register, mobilize, and educate college students to engage in the electoral system, we take care to distinguish between advice 
based on anecdotes or observational studies, and those based on randomized controlled trials that isolate the effect of specific "treatments" or approaches to youth engagement. As Donald Green and Alan Gerber remind us, campaign "war stories" are no substitute for data, and the problem of drawing conclusions from anecdotes persists even when campaign veterans are equipped with many war stories and some statistical analysis, too. ${ }^{13}$ Statistical analysis of survey data or historical turnout data addresses some of the concerns about the generalizability of "war stories," but often cannot overcome the basic fact that correlation does not prove causation. Asking a survey respondent if and how they were encouraged to vote is unlikely to produce reliable information. Even if the voter recalls the contact correctly, they may have been targeted because of their high propensity to turnout, making the perceived boost in turnout a cause, rather than an effect, of the contact. Looking back at historical voting records and mobilization activities solves problems with differential recall, but selective targeting remains and potentially clouds the ability of the researcher to confidently attribute differences in voter turnout to the tactic of interest. High turnout in areas canvassed by specific groups may reflect targeting of highpropensity voters by the groups rather than effective canvassing. ${ }^{14}$ If college administrators are going to be make the investment to adopt mobilization tactics, they should base those decisions on the best available information.

Our review of the get-out-the-vote (GOTV) literature focuses primarily on results produced by employing randomized field experiments. In basic versions of such experiments, a defined population (e.g., full time students) is randomly divided into a treatment and a control group. The treatment group receives the intervention to be tested in the study (e.g., a classroom presentation). The control group receives no special attention from the experimenter, especially the treatment intervention. Because assignment to the two groups is randomly determined, there are no pre-existing differences between the two groups. On average, the treatment and control groups should have equivalent ages, history of electoral engagement, GPA, work schedules, family income, interest in politics, and any other potential cause of voter turnout. The only systematic difference between the treatment and control group is the application of the treatment intervention of interest. Thus, when voter turnout is measured at the end of the experiment, any difference in voter turnout can be attributed to the effect of the intervention. In this way, the experiment allows the researcher to make a causal claim about the effect of the intervention on the turnout of students in the experiment.

Ideally, scholars replicate the experiment at other times and places to determine whether findings are generalizable to different voters and different political contexts. Groups seeking to mobilize young voters must consider the applicability of past studies to their own particular circumstances and goals. The ability to utilize specific methods is constrained by access to resources of money, people, technology, and time. ${ }^{15}$ Given resource limitations, it makes sense to focus on tactics that work.

What, then, do such experiments teach us about how to increase voter turnout? What implications do such studies have for people seeking to boost voting among college students? We share findings from experiments conducted on and off college campuses, whether or not they specifically target (traditional) college-age voters. We take care to indicate when experiments directly targeted college students versus when we are extrapolating from other experiments with clear implications for mobilizing college youth. 


\section{Missing Research about What Works Best to Mobilize College Students}

A large number of national organizations have devoted considerable attention to reclaiming the civic mission of higher education. The American Association of Colleges and Universities (AAC\&U), American Association of State Colleges and Universities (AASCU), national and state chapters of the Campus Compact, and NASPA (student affairs administrators in higher education) are just a few of the national organizations devoted to boosting civic and political participation among U.S. college students. AASCU's American Democracy Project and NASPA's Lead Campus initiative work collaboratively to host an annual Civic Learning and Democratic Engagement conference each summer. From the start, the conference - and the sponsoring partners - have placed a heavy emphasis on the importance of political participation, including voting. ${ }^{16}$

Recent conferences have featured several sessions encouraging campuses to participate in the National Study of Learning, Voting, and Engagement (NSLVE) administered by the Institute for Democracy \& Higher Education at Tufts University. More than 1,000 campuses (and over 10 million students) from all 50 states and all institution types participate in the study which tracks and reports registration and voting rates at each campus. ${ }^{17}$ Over 754 campuses in 48 states (and DC) have also joined the All-In Campus Democracy Challenge, a competition-like program that recognizes colleges and universities that are successful in increasing student voting rates. ${ }^{18}$ Even the American Political Science Association has increased its attention to promoting civic and political engagement, publishing two books on teaching civic engagement, both of which include an explicit argument that political scientists should be doing more to boost student turnout rates. ${ }^{19}$ Given these organizations' commitment to increasing student participation, and their access to important decision makers on college campuses, one would think that there was a substantial literature on mobilizing college students to vote.

Despite this national push to boost civic learning and democratic engagement, there has been a remarkable lack of scholarly attention to campus efforts to boost voter turnout. Only a handful of field experiments have been carried out on college campuses to explicitly test the effectiveness of campus administrators, faculty, staff, and associated groups in getting students to register and cast their ballots. ${ }^{20}$ This hole in the literature is especially surprising since there have been thousands of off-campus voter mobilization field experiments conducted in the past 20 years and tens of thousands of studies using students as subjects in psychology, economics, and education departments. For some reason, few scholars saw students as viable subjects for voter mobilization research.

The major collaborative field experiments in which these organizations partnered with researchers were two national multi-campus voter registration experiments conducted in partnership with researchers Elizabeth Bennion and David Nickerson in 2006 and 2010. ${ }^{21}$ Hopefully with a few proof-of-concept experiments in the rear-view mirror, and a renewed emphasis on increasing civic participation among students, university collectives will be more open to partnering with researchers to rigorously evaluate mobilization activities. 
The recent creation of a coalition with the explicit goal of "increasing student voter participation and diverse engagement through data-driven approaches,” the Students Learn Students Vote Coalition, should prove helpful in producing and sharing rigorous research findings in the future. With monthly conference calls, resource pooling, and information sharing, the group boasts over 300 coalition partners (see Appendix A), all of whom share a common goal and offer extraordinary opportunities for future experimentation on college campuses. ${ }^{22}$ Indeed, some of the SLSV coalition partners have begun to team up with academic researchers to conduct field experiments testing the Party at the Polls concept and other novel approaches to getting out the youth vote (see Election Day Festivals below).

To be sure, the groups provide a wealth of ideas to campuses seeking to promote voter engagement. The best of this advice focuses on the strategic and intentional climate and behavior of institutions that have made significant gains in students' electoral engagement. ${ }^{23}$ However, most of the advice is primarily based on anecdotal evidence, observational data, and small qualitative case studies. Sharing "best practices” and experience-based advice is valuable and can reduce hurdles to campuses adopting mobilization campaigns. The next step in the evolution of this active collective is to rigorously evaluate the efficacy of the advice offered. Rigorous experimental evaluation will provide convincing estimates of the return on investment that schools can anticipate from engaging in mobilization activities. The next sections of this paper aim to take the first step by summarizing our existing knowledge and setting a research agenda for the future.

\section{Voter Registration: A Pre-Requisite to Electoral Engagement}

In the United States, voter registration is a prerequisite for casting a vote. However, the exact role of registration in shaping voter turnout has been the subject of serious debate. Some scholars and political practitioners see registration as an impediment to voting, arguing that once the barrier is removed most people will vote. ${ }^{24}$ Others suggest that the decision to register is evidence of a desire to vote and that those who fail to register are unlikely to cast a vote even if this barrier is lifted. ${ }^{25}$ Yet others take the middle road, arguing that some unregistered people will vote if they become registered through relaxed registration rules or contact with active voter registration drives. ${ }^{26}$ Most of this research is based on large-scale changes in laws and does not address how best to register college students to vote. What do we know about the best way to register voters in general and students in particular? And equally, if not more, important, what do we know about whether registering more voters actually increases turnout on Election Day?

\section{What We Know about Registering College Students to Vote}

Data from the National Study of Learning, Voting, and Engagement (NSLVE) shows that college student registration rates increase dramatically closer to an election, particularly from August through early November. ${ }^{27}$ The Center for Information \& Research on Civic Learning and Engagement (CIRCLE) consistently finds that young adults in states with same-day registration have higher turnout rates than those living in states that do not. ${ }^{28}$ Given that many young people wait until they get to school to register, and many also change addresses to attend a 
college or university, these findings comport with expectations and suggest that campuses need to educate students to help insure that they are registered to vote and know where to cast their ballots. $^{29}$

\section{Evidence from College Campuses: Classroom Registration Works}

An important lesson for people wishing to register high school and college students is that classroom-based registration drives work. Elizabeth Bennion teamed up with David Nickerson in 2006 to conduct a nationwide classroom registration experiment. This 16-campus study involving 22,256 students in 1,026 classrooms found that registration increased by 6 percentage points, and voting increased by 2.6 percentage points as a result of the classroombased registration drives. ${ }^{30}$ That is, every 10,000 students targeted yielded 600 registrations and 260 votes. ${ }^{31}$ This mobilization effect, while small, is based on a registration drive alone that took only 10 minutes of classroom time and did not include any follow-up with new registrants to mobilize their votes. ${ }^{32}$

Interestingly, this multi-campus experiment did not reveal any statistically significant difference in the effectiveness of professor and peer presenters. This finding makes it easier for campuses to reach students in the classroom through a combination of DIY faculty presentations

and peer outreach efforts in classrooms where faculty prefer not to register their own students. ${ }^{33}$ This null finding strongly suggests that the act of conducting the registration drive to a semicaptive classroom audience matters more than the authority of the person making the presentation.

\section{Evidence from College Campuses: Email is Ineffective at Registering New Voters}

Classroom-based registration drives, while effective, are labor intensive and timeconsuming to coordinate. A simpler approach to meeting the federal government's requirement to distribute registration forms to all enrolled students is to send a mass email to students including a link to a printable registration form. ${ }^{34}$ While this email-based approach complies with the law, it has proven ineffective in producing new registrants or voters.

Bennion and Nickerson conducted a large-scale, multi-campus voter registration field experiment involving over 250,000 students on 26 college campuses leading up to the 2006 midterm elections. Email outreach proved ineffective at registering new voters, regardless of the message or sender, with registration rates in the treatment group actually declining by 0.3 percentage points. ${ }^{35}$ The authors hypothesize that students who got the email reminders to register may have put off doing so, knowing that the information was available to them anytime. Further they suggest that, confident in the knowledge that they have the information required to register waiting in their INBOX, students may have skipped more effective registration opportunities such as hallway registration tables staffed by volunteers who audit and submit the registration forms without additional work by the students registering to vote. 
Bennion and Nickerson tested the effectiveness of registering students to vote through email outreach once again before the 2010 registration deadline, this time testing whether linking students directly to an online registration system might increase the effectiveness of email outreach. The experiment involved over 200,000 students on 25 campuses in states with online voter registration. Students were randomly assigned to one of three treatment conditions: a control group receiving no email; a treatment group that received a link to a downloadable PDF like in the 2006 experiment; or an email linking to the Secretary of State's online voter registration system. There was no detectable effect comparing all students in the treatment group to those in the control group. Among the 130,000 students who had never been registered before, the treatment linking students to the downloadable form increased registration rates by 0.6 percentage points (se $=0.3$ ), which was a surprising finding given the prior experiments. Linking students to the online voter registration form was even more effective, increasing registration rates by 1.2 percentage points $(\mathrm{se}=0.3$ ) among students never registered to vote before. Looking at the downstream effect of the registration intervention on turnout leads to an interesting pattern. Linking to the downloadable form did not increase turnout among the students not previously registered $(-0.1 \mathrm{pp}$, se $=0.2)$ whereas turnout increased by 0.7 percentage points (se $=0.2$ ) for unregistered students sent an email containing a link to the SOS registration portal. That is, registrations generated from the downloadable form did not increase turnout at all while $58 \%$ of the boost in registration from the online portal translated into votes. The increase in turnout translates into 7 votes for every 1,000 students sent an email linking them to the state online registration portal. ${ }^{36}$ Although the magnitude of the effect is not large enough to close the gap in turnout between Millennials and Boomers, the fact that there is very little cost involved in sending out thousands of such emails makes this a potentially useful supplement to other, more labor intensive, approaches to registering and mobilizing college students.

Moreover, relatively passive registration tactics like downloadable forms can increase turnout when paired with follow up nudges to mail the form into the proper offices. In 2008, Rock the Vote conducted an experiment in Pennsylvania and Indiana to measure the effect of sending reminder text messages to users who had filled out and downloaded registration forms. ${ }^{37}$ As the registration deadline neared, users were randomly assigned to a control group that received no follow-up text or a treatment group that received a text message reminding the user that the deadline was rapidly approaching. In both states, users assigned to the treatment group were 4 percentage points more likely to return the forms and be registered to vote. This experiment suggests that simple nudges from officials can increase compliance among students who expressed interest in registering to vote and took the initial steps required to do so.

In summary, time and effort spent registering voters is well worthwhile. Personal appeals that accompany the distribution and collection of registration forms are more effective in boosting registration and student turnout rates than more impersonal approaches like email. Online registration systems increase the effectiveness of email outreach, but the effect is still quite small, pointing to the need to try additional high impact approaches to voter registration. The concern that "doing the work" for the voter by soliciting, supervising, and completing the registration process will merely result in the registration of non-voters is not supported by the data. Not only is registration a prerequisite for voting, but registration drives have a small, but statistically significant, effect on voter turnout itself. 


\section{Other Relevant Studies: Registration Drives Produce Votes}

The finding that successful campus registration drives also produce new voters is consistent with experimental results gathered outside of college campuses. For example, David Nickerson conducted field experiments across six cities, randomly assigning 620 streets to a treatment group that received canvassing to increase registration rates or to a control group that received no contact from the campaign. He then tracked the rate of new registrations on each street, as well as the number of votes cast on each street by newly registered voters. The experiments took place in a variety of political contexts including presidential, congressional, and off-year gubernatorial races. On average, 10 more newly registered people appeared on treatment streets than control streets - an increase of $4.4 \% .{ }^{38}$ Treatment streets also averaged two more votes than control streets, meaning that $24 \%$ of the people registered as a direct result of the registration experiment voted. ${ }^{39}$ A meta-analysis of registration experiments by Green and Gerber concludes that voter registration drives are effective in boosting turnout, generating one new vote for every three or four new registrants. ${ }^{40}$ This is consistent with Bennion and Nickerson's research directly targeting college student voters.

Drawing upon these findings, Northwestern University created a new campus plan to increase student electoral participation, which included resisting the temptation to contact "incoming digital natives" by email. University officials reasoned that efficient outreach that addresses thousands of students at once may be inherently counterproductive, causing newly eligible students to feel insignificant and to wonder if their one small vote is worth the cost of paying attention to politics and navigating the bureaucracy. ${ }^{41}$ To counter these obstacles, the university turned to highly personalized, individualized approaches, including a decision to respect students' preference to vote back home by mail. ${ }^{42}$ Rather than assuming that absentee voting is too complicated, the university created a program using peer mentors to greet each student individually, explain voting choices and assist with registration -- and with an absentee ballot application. The university's decision to mandate a conversation with every incoming student has resulted in a 95 percent registration rate (excluding students ineligible to vote). ${ }^{43}$

The Northwestern program is designed to affirm individual value by providing one-onone attention to each potential voter, while also sending a clear message that the university views civic participation as "part and parcel of being a college-age adult." 44 Although this is an isolated case study, not subjected to randomization or cross-campus comparisons, there is compelling evidence that this approach has been effective in boosting student voting rates. A 95\% registration rate is above any plausible baseline rate that a university - even one as elite and affluent as Northwestern - would expect. The university's record-setting voter registration program raised Northwestern students' turnout - which was a typical 49 percent in 2012 - to 64 percent in 2016, well above the 58 percent national average for citizens of all ages. ${ }^{45}$ This model has also been successful at the University of Illinois at Chicago (which won an ALL IN Campus Democracy Challenge award based on improvement in their NSLVE data after they replicated much of the Northwestern plan).

Registering students to vote and educating them about absentee ballot options is not a simple mechanical process. Campuses should also educate students about acceptable forms of identification for in-state, in-person voting (such as a U.S. passport, free state ID, or state-issued 
student identification card). ${ }^{46}$ Unless prevented by state law, campuses can also take affirmative steps to change their student identification cards to make them compliant with state voter ID laws, as Indiana University did (for all IU campuses) in 2017. Colleges that continue to shepherd their students through the voting process will likely increase voter turnout beyond any turnout gains expected from running the registration programs alone. The next section discusses the challenge of getting students to the polls once they are registered.

\section{Voter Mobilization: Getting Young Americans to the Polls}

There are many ways to mobilize voters. In all cases, the goal is to get people to cast their ballots on, or before, Election Day. This section of the paper highlights experimental research findings about the best way to get people to the polls, noting the relevance of each finding for those seeking to mobilize college student voters. Very little published GOTV research has been conducted on college campuses, but many research findings established in the literature have important implications for college student mobilization.

\section{Traditional GOTV Techniques}

Door-to-door canvassing, leafletting, and yard signs are all traditional approaches to voter mobilization. These techniques are utilized in local, state, and national political campaigns to get out the vote. How well might these approaches fare on college campuses? A careful review of the literature gives us many clues.

Door-to-door Canvassing. Door-to-door canvassing is the mobilization tactic that has demonstrated the largest treatment effects over two decades of experiments. Several lessons have emerged from field experiments using this face-to-face mobilization technique. First, contacting eligible voters can be challenging. Multiple return trips are often required to achieve a contact rate of $25 \%$. This can, perhaps, be mitigated to some degree by targeting college students in their dorms before their 10 A.M. morning classes or on school nights, but catching students at home can still be a challenge. The effort, however, seems to be well worthwhile. When canvassers are able to contact potential voters, they generate votes. ${ }^{47}$ On average, door-to-door canvassing generates one vote per 15 contacts (not including any "spillover" effects on housemates). ${ }^{48}$ In fact, when comparing the mobilization of younger and older voters, younger voters have been shown more difficult to contact but equally responsive to the contact once it has been made. ${ }^{49}$ Thus, labor intensive mobilization strategies like door-to-door canvassing are likely to increase turnout.

These mobilization efforts are likely to have the biggest effect in lower salience local elections. The effectiveness of the canvassing varies by election and voter type. ${ }^{50}$ Past studies suggested that canvassing has the biggest effect on the people already most likely to vote during low profile elections (e.g. municipal elections), while canvassing has the biggest effect on the people least likely to vote during high profile races (e.g. presidential elections). ${ }^{51}$ While campuses generally spend the most resources mobilizing voters in congressional and presidential general elections, these efforts are likely to offer the lowest return on investment. Engaging 
students in off-cycle state and local elections that do not receive much media attention is likely to yield the largest mobilization effects. Canvassing can be effective even in uncompetitive electoral settings, ${ }^{52}$ therefore colleges and universities are well-advised to make a serious effort to register and mobilize voters during every election season, rather than focusing solely on highprofile, competitive races.

Making the contact encouraging turnout at all is more important than matching the identity of the canvasser to the voter or customizing what is said to each voter. ${ }^{53}$ That said, there is some evidence that co-ethnics may be more successful in targeting members of their own ethnic group ${ }^{54}$ and canvassers, in general, may be more effective in mobilizing people from their own community. ${ }^{55}$ Although more evidence is need to support the theory that people are best mobilized by canvassers from a similar background to their own, the diversity and student engagement goals of most colleges and universities would be best served by recruiting a diverse team of college student canvassers to target their peers when conducting campus get-out-the-vote campaigns.

Campuses with residential buildings are particularly amenable to door-to-door mobilization campaigns. Mobilizing students by going door-to-door in campus housing units is not only efficient, when compared to mobilizing rural voters in their households, it also carries another potential benefit. Past research has demonstrated that those who receive a get-out-thevote message communicate about the upcoming election to their housemates, with as much as 60 percent of the direct impact of canvassing transmitted to other members of the household. ${ }^{56}$ This finding suggests that “dorm storms” and other efforts to mobilize students living in dormitorystyle or apartment-style campus housing may have an effect on others living at the same residence, even those who are not home when the canvasser visits.

Leaflets and Signage. How important is it for people to be home when canvassers arrive at their doorstep to deliver a get-out-the-vote (GOTV) message? Studies of leafletting suggest that it has a much weaker but measurable effect on voter turnout than face-to-face conversations at the door. ${ }^{57}$ A weighted average of eleven studies conducted between 1998 and 2006 suggests that leaflets increase turnout by about 0.6 percentage points. For every 189 registered voters leafletted, one additional vote is produced. ${ }^{58}$ While this effect is weaker than door-to-door canvassing, it is also much quicker and easier to do. Leafletting allows volunteers to reach far more voters and there is no evidence that young voters are less responsive to leaflets than older voters. ${ }^{59}$

The substantive content on the leaflets themselves have not mattered a great deal in field experiments. There is some (inconsistent) evidence that door hangers providing information about polling locations and local candidates may be more effective than standard leaflets. ${ }^{60}$ Attempts to boost turnout by informing voters about election protection, bilingual ballots, or the need for voter ID have proven ineffective at boosting participate rates over generic leaflets. ${ }^{61}$ Thus, producing leaflets need not be a time intensive process with complicated personalization strategies. Modest gains in voter turnout can be realized in a cost effective manner through the use of relatively simple leaflets. 
Signs encouraging students to vote are another way campuses can increase visibility surrounding elections. Are such signs likely to increase turnout? Green and Gerber (2015) summarize the results of five experiments gauging the effects of campaign signs including roadside signs, ${ }^{62}$ yard signs, ${ }^{63}$ and handheld signs on Election Day. ${ }^{64}$ Based on their review of this literature, they conclude that signage on private property or along roadsides has no statistically significant effect on turnout, but that handheld signs advertising an upcoming election may boost turnout. ${ }^{65}$ However, more research is needed to determine whether the apparent three percentage point boost in turnout reported for a New York City municipal election is a generalizable effect or the result of context or chance. ${ }^{66}$ Based on past research, students and other activists seeking to mobilize the college student vote should not confine their voter mobilizing efforts to placing yard signs across campus reminding students to vote. A better approach would seem to be asking student volunteers (or paid canvassers) to hold signs encouraging their fellow students to vote, while also talking face-to-face with their peers, mobilizing them in dormitories and classrooms, and encouraging students to attend Election Day parties and parades to the polls. Next, we turn to a discussion of campus gatherings and events, including debates, Election Day festivals, and other innovative approaches to boosting voter turnout through increased campus engagement.

\section{Events and Campus Gatherings}

A popular way to build student excitement surrounding elections is through campus gatherings and events. Although experimental research in this area is still fairly new, the best available data suggests that such events represent valuable, inexpensive, and effective supplements to more traditional approaches to voter mobilization. Two such activities include candidate forums and Election Day festivals. Intra-campus and inter-campus competitions and first-time voter programs are other promising approaches to mobilizing student voters.

Candidate Debates. Colleges and universities often partner with local community organizations to host debate watch parties and live candidate debates on campus. Are those who watch or attend debates already determined to vote? To what extent can such activities boost voter turnout?

An experiment conducted among a nationally representative sample of voters in 1980 was analyzed by Adria Lawrence and Bethany Albertson. Lawrence and Albertson found that people who were randomly encouraged to watch the presidential debates showed a greater intention to vote. ${ }^{67}$ A follow-up study by Sendhil Mullainathan, Ebonya Washington, and Julie Azari, in the context of a 2005 New York City mayoral campaign, found similarly positive results, though the results of the authors' analysis (based on random encouragement followed by consultation of the voter files) fell short of statistical significance. ${ }^{68}$ Although more research is needed, these findings suggest that encouraging people to watch candidate debates by hosting well-publicized debate watch parties on campus may do more than increase voters' knowledge of policy differences among the candidates; such viewing may also increase voter turnout.

What about hosting live debates on campus? Can such events affect voter turnout? David

Nickerson studied a creative meet-the-candidates event called "Candidates Gone Wild."69 This 
event, hosted at a local theater by the Oregon Bus Project and a local countercultural newspaper is described by Nickerson as "a high-energy amalgam of a political debate, the Gong Show and David Letterman's Stupid Human Tricks.” The show, which took place two weeks before Portland's 2006 primary election, featured candidates running for city and county offices. By randomly assigning 50 of the 1000 tickets (from a pool of 100 interested local citizens), Nickerson found that those who attended the events were more familiar with the candidates, but retained very little substantive information about their platforms or positions. They were also no more likely to express an interest in politics or to think that voting is important than those who were not selected to attend the event. However, attendees were more likely to think that local politics is important. Strikingly, despite the seemingly similar attitudes toward political participation that members of the treatment and control groups expressed in post-event surveys, members of the treatment group were much more likely to cast a ballot. ${ }^{70}$ The small size of this experiment, and unique nature of the event, leads us to be cautious in drawing conclusions about the mobilizing effects of attending a candidate forum, but the "random invitation" design is one that should be used in future experiments to study the effectiveness of such invitations on voter knowledge, attitudes, and participation rates. The format of this creative candidate event is also interesting to consider when attracting young people, including college students, to live candidate forums and debates. ${ }^{71}$

Election Day Festivals. Intrigued by the idea of attracting young voters by making voting more social and fun, a handful of small-scale studies conducted in 2005 and 2006 suggest that Election Day festivals can increase voter turnout, especially in low-profile (i.e. low salience) races. In 2005 and 2006 Elizabeth Addonizio, Donald Green, and James Glaser sought to attract voters by creating a festive and community-focused atmosphere at the polls. ${ }^{72}$ Over two years, the authors coordinated sixteen alcohol-free, family-friendly festivals held in a wide variety of locations and engaging a wide variety of different demographic groups. The authors first pilot tested the project by selecting two New Hampshire towns with similar demographics and voter turnout histories. They flipped a coin to see which community would be invited to a festival and which would serve as the control group. A week of publicity, including flyers, posters, lawn signs, pre-recorded phone messages, and media coverage, preceded the festival. The Election Day festival (complete with snacks, drinks, raffles, and music) was a great success. Turnout in the treatment community exceeded that of the control community, despite having no contested candidates on the ballot. After replicating the experiment in New Haven, the authors partnered with Working Assets to host festivals (and assign randomly selected control precincts) in every region of the country in 2006. Across the 38 precincts, the authors discovered that the festivals, and the pre-publicity surrounding the festivals, increased voter turnout by two percentage points. The festivals produced mobilization effects on par with more traditional mobilization techniques and at a relatively small price, placing them among the most cost-effective mobilization strategies studied to date. ${ }^{73}$

Given the promising nature and cost effectiveness of Election Day polling place festivals, Donald Green and Oliver A. McClellan decided to test the effectiveness of such festivals during a high salience presidential election. The researchers worked with Civic Nation to coordinate a series of non-partisan election festivals designed to encourage voter turnout in targeted precincts across the United States. They hypothesized that precincts in which poll location festivals are held would see increased turnout compared to control precincts in which Civic Nation pursued 
no mobilization activities. Given Addonizio et al.'s (2007) estimated effect of a 2 to 3 percentage point boost in turnout during low salience elections, Green and McClellan predicted a 6 to 7 percent boost in turnout during a high salience, higher turnout, presidential election. Using block randomization to assign precincts to treatment or control conditions, the authors compared voting rates of the two groups. With eight sets of voting precincts, the experiment was too small to isolate the turnout effects of election festivals, and the advertising that preceded them, with great precision, but the authors report a 3.8 percentage point (average) boost in turnout in the treatment precincts. ${ }^{74}$ At a total cost of $\$ 27,922$ and an average increase of 829 votes per precinct, the authors concluded that festivals rank among the most cost-effective get-out-the-vote techniques available. ${ }^{75}$ It is important to note, however, that more research is needed to understand how GOTV efforts leading up to the festivals, pre-festival outreach and advertising, and uncontrollable factors like the weather might alter the effectiveness of the festival approach. ${ }^{76}$

Election Day vote festivals (e.g. Party at the Polls) lend themselves well to mobilizing college students, especially on campuses with on-campus polling places. Such festivals could also prove valuable at campuses with large numbers of residential students who register to vote using their campus address (and, therefore, vote at the same polling place). Campuses that attract large numbers of county residents who can vote at the same (early voting or Election Day) vote center could also utilize a Party at the Polls model. Only one study - scheduled for release November 2018 - has studied the effects of festivals specifically designed to mobilize college student voters. With only five pairs of locations, the researchers were unable to discern any noticeable boost in voter turnout in precincts where partisan election festivals were hosted by a political advocacy group during the final days of the 2016 presidential election. ${ }^{77}$ Although these experiments were conducted on college campuses, the actual festivals did not take place on campus and were not hosted by the campuses themselves, opening up an important direction for future research.

Election Day festivals are best suited to campuses with onsite precincts, but can also be adapted to adjust to a Parade to the Polls model where students hold a party on campus that energizes students to vote and then parade, caravan, bus, or carpool to the polls together. Hats, buttons, t-shirts, and signs can be created to build enthusiasm and attract both traditional and social media attention as students parade together to the polls. ${ }^{78}$ Colleges can also target out-ofstate students by hosting ballot completion parties complete with stamps and mailing stations for students submitting absentee ballots. ${ }^{79}$ More experimentation is required to test the effectiveness of the many possible variations on the festival theme. Campuses have many potential advantages in organizing such festivals. ${ }^{80}$ The Election Day festival ("Party at the Polls") model holds great promise for mobilizing a population that is eager to enjoy campus life and make new friends.

GOTV Competitions. The IDHE's National Survey of Learning and Voter Engagement (NSLVE) includes voting data from more than 10 million students on over 1,000 campuses in all 50 states. The data has unearthed a series of insights about student voting behavior in the 2014 and 2016 elections and this data could help campuses target the kinds of students who are not voting rather than focusing on the types of students who already vote at high rates. ${ }^{81}$

Although Nancy Thomas and her team at the IDHE never envisioned the study as a way to create competition between campuses, the emergence of data has led schools to compete with 
one another over voter turnout, which is increasingly seen as a proxy for a politically engaged student body. ${ }^{82}$ Such competition is encouraged by the ALL IN Campus Democracy Challenge, a national awards program that awards Bronze, Silver, and Gold seals based on the percentage increase in a school's voter participation rate, as well as "Best in Class" awards for highest turnout and most improved turnout based on institution type and size. ${ }^{83}$ Such competitions are welcomed by campus leaders concerned about low voting rates in their student body. Dr. Edie Goldenberg, a political science professor at the University of Michigan in Ann Arbor, was shocked to learn that the percentage of students at the school who voted in the last midterm election was just 14 percent. The problem was not confined to the Michigan campus. Data suggests that only 18 percent of all college students voted in 2014, compared with about 37 percent in the overall population. After setting a goal to double student turnout at the University of Michigan (Ann Arbor campus) during the November election, Goldenberg encouraged the university to challenge their Big Ten football rivals to a competition to see which school could get the most students to vote in $2018 .{ }^{84}$ Fourteen campuses accepted the invitation to participate in the Big Ten Voting Challenge, teaming up with TurboVote to get students registered, send them email and text reminders, and help them apply for absentee ballots. Trophies will be awarded to the campus with the highest eligible voter turnout and the campus with the most improved turnout. ${ }^{85}$

With campus pride at stake, campuses are using a range of creative approaches to boost student voter turnout and beat the competition. ${ }^{86}$ As noted earlier, Northwestern University voter registration was integrated into new student orientation with one-on-one peer advising for all students. New York's Binghamton University is giving out prizes - such as foosball tables or television sets - to the residence hall that registers the highest percentage of voters. Although such approaches have not yet been subjected to rigorous analysis that isolates the effects of specific interventions, NSLVE data does allow campuses to measure students' overall boost in turnout based on comparable elections in the past. ${ }^{87}$ ALL IN Campus Democracy Challenge and the IDHE are using this data, combined with campus case studies, to develop a list of recommended best practices and generate hypotheses to be tested through additional research.

First Time Voter Programs. The First-Time Voter Program is a school-based outreach effort designed to encourage high school seniors to vote. A young volunteer leads an informal and interactive seminar focused on giving students the experience of registering to vote and casting a ballot using the type of machine used in their jurisdiction. The instructor asks students to share their perceptions about voting and Election Day, allowing them to voice their fears and concerns. The presenter discusses the relevance of voting to issues the students care about (e.g. curfews, texting while driving, and college funding) and talks about the power of young voters as a group. The presenter also provides the students with registration forms, explains how to compete the forms, collects the forms, and explains the rules for absentee balloting. Finally, the presenter unveils the voting machine, explains how it works, and invites students to complete a ballot and cast a vote. This 40-minute, 30-student presentation results in about 90 percent of the students casting at least one ballot, allowing them to become "experienced" voters before casting an official ballot during their first election season.

In an experimental study of the First-Time Voter Program conducted before the fall and spring elections of 2003 and 2004, Elizabeth Addonizio randomized program participation 
among eligible seniors in six states. Program participants turned out to vote at a rate of 10 percentage points more than students in the control group. ${ }^{88}$ It is unclear whether reduced apprehension about the voting process or an elevated sense of community and commitment to public affairs caused the boost in turnout, but such programs could be replicated, and tested, at the college level. Freshman seminars would be a particularly appropriate venue for such experiments. Longitudinal studies could determine the long-term effects of such programs.

\section{Other Traditional GOTV Techniques}

Unfortunately, door-to-door canvassing drives (e.g. dorm storms), Election Day vote festivals, and other campus-wide events are highly labor intensive and it is unlikely that all students - or even a majority of students - will participate. Are there ways that administrators can use the student directory to contact all enrolled students directly with GOTV appeals that may prove effective at moving students to the polls?

Direct Mail. Direct mail is a staple of political campaigning at the local, state, and national levels. Local and state campaigns often spend the bulk of their budgets on direct mail. Is this spending warranted? Should colleges and universities, who have access to students' campus and permanent addresses, invest resources in direct mail GOTV outreach to enrolled students?

Generally speaking, direct mail is not cost-effective at increasing turnout. ${ }^{89}$ As Green and Gerber explain, mobilizing voters is not merely a matter of reminding them about Election Day. Live reminder calls from commercial phone banks, email reminders, Facebook reminders, and reminders sent by direct mail all have weak (or negligible) effects. ${ }^{90}$ Adding a voter guide or telling people who they should vote for does not seem to enhance the effectiveness of direct mail. ${ }^{91}$ Pooling together 85 field experiments conducted between 1998 and 2014, Green and Gerber (2015) find that sending a piece of mail increases turnout by about $3 / 4$ of a percentage point. Based on an analysis of existing studies, they calculate that direct mail from advocacy groups has no detectable effect while direct mail from nonpartisan groups employing conventional messages produces one vote per 273 recipients. ${ }^{92}$

The exception to this rule of limited effects is direct mail that includes a social pressure component, such as information about the voting history of the recipient and her neighbors (with or without threats to publish and share this history again following the upcoming election). ${ }^{93} \mathrm{~A}$ meta-analysis by Green and Gerber (2015) calculates the average effect of social pressure mailers to be 2.3 percentage points. Urging people, including nonvoters, to do their civic duty and notifying them that whether they vote is a matter of public record does increase the likelihood that they will turnout to vote. However, such tactics, while effective, carry the risk of generating negative backlash from recipients and the media. ${ }^{94}$ Given that colleges and universities are risk adverse and have ongoing relationships with students and alumni, they are unlikely to pursue the most effective (threat-based) social pressure messaging strategies. A promising means of avoiding this backlash is to thank the student for voting, which reminds the target that voter turnout is a public record but wraps the reminder in a positive frame expressing gratitude. ${ }^{95}$ Of course, even this approach has limited utility when mobilizing students who have never voted before. 
Shaming college students based on their past voting behavior is also unlikely to be effective because many students are young and have not yet established a voting history. There is even some evidence that talking to young people about their low levels of turnout in past elections can further decrease, rather than motivate, future turnout. Lauren Deschamps Keane and David Nickerson sent mail to young Colorado Latinos with a low likelihood of turning out to vote in the 2008 presidential election. One treatment reported that $90 \%$ of young Latinos intended to vote in the election. A second treatment added that only $20 \%$ of young Latinos actually voted in 2006. A third treatment provided the additional fact that $40 \%$ of older Latinos voted in 2006. Compared to the control group, the treatment reporting low levels of prior youth turnout decreased participation in the 2008 election. While the mailings did not achieve their intended result - to encourage young Latinos to vote - the unintended consequence of the campaign provides evidence that appealing to descriptive social norms can affect mobilization, and that shaming young people for their past lack of participation may be an ineffective way to inspire them to turnout in the future. ${ }^{96}$ Taken as a whole, past research suggests that direct mail campaigns targeting enrolled students with GOTV messages are probably not a good use of university resources.

Phone Calls. Campus directories also include student phone numbers. Phone banks are a popular GOTV option for local, state, and national candidates in the United States. Should universities seeking to boost student turnout rates employ people (perhaps even students) to host their own GOTV phone banks targeting enrolled students?

Generally speaking, using direct methods of voter communication, including face-to-face communication and live telephone communication, increases turnout rates, while indirect methods such as electronic, mass media, and mailed communications (e.g. robocalls, mailers, email, television, or radio) have a weak effect or no effect at all in getting voters to the polls (Green \& Gerber, 2015; Garcia Bedolla \& Michelson, 2012). As mentioned previously, door-todoor efforts are labor intensive and time consuming, so making phone calls is a potentially attractive alternative. Unfortunately, people are increasingly unwilling to answer calls from unknown callers making it difficult to do more than leave a voicemail message. However, this decreasing pick up rate tracks with lower open rates of emails and decreasing frequency of people answering doors, so low contact rates do not disqualify phones as a mobilization tactic.

When callers do connect with prospective voters, the effectiveness of the contact is sensitive to call quality. Professional phone banks that pay relatively untrained people to follow a canned script are ineffective at moving people to the polls. ${ }^{97}$ In contrast, personal telephone calls are effective at boosting voter turnout when callers are well-trained, well-supervised, and use a conversational style. ${ }^{98}$ A pooled analysis of studies conducted between 2000 and 2014 estimates that volunteer phone banks produce an average of one voter per 35 contacts, while commercial live calls create one vote per 125 contacts. Meanwhile, robo calls produce an average of one voter per 960 calls, but the effect is not statistically different than zero. ${ }^{99}$ It should be noted that impersonal methods such as robocalls that include a social pressure component can effectively increase turnout ${ }^{100}$ but, as noted earlier, such social pressure messages can generate voter backlash. ${ }^{101}$ 
There are a few scripting tricks that can be employed to increase the effectiveness of phone calls as a mobilization tactic. Building on voters' preexisting level of motivation to vote can boost the effectiveness of phone-based mobilization efforts. Melissa Michelson, Lisa Garcia Bedolla, and Margaret McConnell conducted a series of experiments where subjects were called and asked if they could be counted on to vote, a question the vast majority answered affirmatively. The researchers then randomly assigned these subjects to a control group that received no additional contact or to be called back and reminded of their commitment to vote shortly before the election. They found that subjects reminded of their commitment to vote via telephone were much more likely to vote, and the mobilization effect was as effective as door-todoor contacts. ${ }^{102}$

Helping students to create a voting plan may also boost the mobilization effects of GOTV phone calls. ${ }^{103}$ Asking simple questions about when the person plans to vote, how they will get there, and where they will be coming from is easy to do in a phone call. Another strategy would be to inform students about ballot privacy. Alan Gerber and co-authors conducted a field experiment where the Connecticut Secretary of State mailed letters discussing ballot secrecy to randomly selected voters. The authors found that first-time voters receiving the letters were 3 percentage points more likely to vote than first-time voters in the control group. ${ }^{104}$ Given that a majority of college students have not had the opportunity to vote before attending college, walking college students through the voting process would probably also improve participation rates and could be implemented with phone calls. Given that colleges often have an abundance of volunteers (who are relatively cheap labor), phone campaigns with students calling their peers are worth consideration.

\section{New Approaches to Mobilization: Email, Social Media, \& Text Messaging}

There are several important advantages to electronic/digital communication. Such outreach is cheap, communications can be shared with family and friends (providing additional free exposure), select groups of people can be targeted based on demographics and interests, and embedded links provide easy access to additional resources, information, or opportunities for action. In addition, the content and quality of the GOTV message delivered via text messages, email, or social networking sites are easier to control, guarding against departure from the script and other quality control problems. All of these factors make digital communications an attractive option for mobilizing voters. ${ }^{105}$

Perhaps the easiest way a campus can encourage students to vote is by sending a mass email to all students. Campuses routinely send daily email digests to students to keep them informed about campus activities and email is the official mode of communication at most universities. We have already noted that email messages urging students to register to vote are generally ineffective at generating new registrations. It appears that most people who register after receiving an email invitation to do so would have registered even without the email prompt. Even linking students directly to an online registration system produced very modest results. ${ }^{106}$ Is email more effective if used closer to Election Day to encourage people - including college students -- to vote? 
Email. Email is generally ineffective in boosting turnout. Votes for Students (VFS), a nonpartisan organization created to encourage voter participation by college students, collaborated with colleges across the United States to find out whether or not email could be used to effectively boost student voter turnout. VFS programmers sent emails, monitored the rate at which emails were opened, and varied the percentage of students on each campus receiving the emails (to detect any "contagion effect" caused by people in the treatment group forwarding the emails to friends). The content and frequency of the email varied by campus, though all were contacting during the 2002 midterm election. Roughly 20 percent of the recipients appeared to open at least one of the VFS emails but nearly all the students would have been exposed to the subject lines. Similar to Bennion and Nickerson's 2006 voter registration experiment cited earlier, ${ }^{107}$ matching student names and addresses to the voter rolls to see which students registered or voted revealed that receiving campus emails encouraging registration and turnout had no effect on students' decision to vote. ${ }^{108}$ Studies testing the effectiveness of Youth Vote emails sent using an opt-in email list, and Working Assets emails sent to a list of people who specifically requested to be put on an email list to receive reminders to vote, produced similar null findings. ${ }^{109}$

In sum, research suggests that email messages seldom increase voter turnout. In fact, an analysis of 13 field experiments in three different elections including 232,716 subjects found that email messages were ineffective in raising turnout rates. ${ }^{110}$ This is true even when the sender is credible and partisan loyalty is activated (e.g. Democrats receiving GOTV appeals from the Democratic National Committee). ${ }^{111}$ The only mass email program conducted by non-partisan organizations to demonstrate a positive effect on voter turnout are emails sent from county clerks to registered voters in the area. ${ }^{112}$ Unfortunately, experiments attempting to leverage the authority of college administrators have not demonstrated any ability to increase voter turnout. ${ }^{113}$ Perhaps universities could coordinate with local election officials and invite the board of elections to email students encouraging turnout. However, in general it appears mass email will not appreciably increase voter turnout. ${ }^{114}$

A more personalized email program shows promise for mobilization, however. Experiments testing friend-to-friend email campaigns have shown promise in increasing turnout. ${ }^{115}$ The experiment entails participants having their friends/contacts randomly assigned to one of three conditions: no email, mass email, or personalized email. Replicating this networkbased mobilization strategy would be very challenging in most contexts, but college campuses seem ideally situated to try them out. College students are digital natives and have densely overlapping social networks. A small group of volunteers could actually reach a large portion of a university and take advantage of any additional leverage from social networks.

Social Media. Campuses have sought new ways to communicate with students out of a growing frustrating that students frequently ignore campus email accounts, believing that "e-mail is for old people." ${ }^{116}$ Even students who spend hours each day online, both for work and play, seldom check their campus email accounts. ${ }^{117}$ For this reason some campuses have turned to social media platforms to reach out to student voters. What do we know about the effectiveness of such campaigns? 
On the whole, research suggests that social media ads are ineffective, but peer-to-peer outreach shows promise. Impersonal messages delivered via a social media platform have proven ineffective at increasing voter turnout. A massive study of 61 million users during the 2010 midterm election produced two important findings. First, social media information campaigns consisting of prominently displayed banner ads and "I voted" widgets are ineffective at promoting voter turnout. And, second, large-scale social media campaigns raise turnout only when users are also presented with news showing which of their friends have voted. ${ }^{118}$ The average effect of such customized social media mobilization is small, but statistically significant, with an estimated one vote produced for every 256 users. ${ }^{119}$ Although the effect is small, the potential remains large with 2.23 billion monthly active Facebook users worldwide. ${ }^{120}$ However, short of teaming up with Facebook, an experiment that requires changes to the Facebook platform is not something ordinary groups - including college campuses -- can replicate. Ads are no substitute for such personalized (friends-to-friend) messaging. A series of experiments conducted by Rock the Vote in 2012 and 2013 confirmed that Facebook ads - an approach available to any group willing to pay -- were ineffective at increasing voter turnout. ${ }^{121}$ Consistent with other research on effective GOTV techniques, it seems that personalized (and socially connected) GOTV appeals are more effective than less personalized approaches.

One way to increase the effects of social media outreach is to personalize the messaging through friend-to-friend communications. Professor Holly Teresi tested this approach by encouraging students to friend her on Facebook. She randomly divided the (roughly 600) students into a control group that received updates on nonpolitical topics and a treatment group that, in addition, received fourteen updates on topics related to the upcoming 2010 general election. Friend-to-friend communication about an upcoming election appears to increase turnout. Matching student Facebook profile information to the Georgia voter file revealed a substantively and statistically significant treatment effect despite the fact that only half of the students were located on the voter files. Teresi and Melissa Michelson report that exposure to GOTV Facebook messages boosted turnout in the treatment group by 8.22 percentage points (and by $10.6 \%$ for those under 30 years old). These effect sizes rival door-to-door canvassing and are much larger than usually found for indirect GOTV methods. ${ }^{122}$ In effect, Teresi produced one vote for every twelve friends who were encouraged to vote through a series of chatty posts in their news feeds. Katherine Haenshen (2016) found similar results by having participants in an experiment tag randomly selected friends in status updates about the importance of voting. ${ }^{123}$ Replication is needed, but these studies suggest that professors may harness the power of social media in ways that promote political engagement, and that student leaders (or administrators) can train students to mobilize their friends using social media sites and applications. Keeping up with the changing social media habits of young people is a challenge, but personalized (friend-tofriend) social media outreach may be a powerful way to increase registration rates among college students and other young voters.

While universities themselves can post encouragements to register and vote on their official social media channels, the low usage of such sites at most campuses suggests that that students are unlikely to see such posts. This means that individual administrators, faculty, or staff will need to "friend" students to gain access to their personal newsfeeds. Alternatively, students can be trained and encouraged to reach out to their peers on social media. Given the reluctance of most faculty and administrators to "friend" students - and the concerns about overreach and 
appropriateness that such requests might cause - it seems like working with student leaders in classes, clubs, and student organizations to promote peer-to-peer mobilization through their group sites and personal newsfeeds may prove to be the most realistic and effective option for harnessing the potential mobilizing effects of a social media platform. More research on effective uses of various social media platforms is needed as the average age of Facebook users rises.

Smartphone Apps. In addition to documenting the positive effects of friend-to-friend Facebook mobilization, Melissa Michelson also found positive mobilization effects using the popular smartphone application WhatsApp. Mauricio Moura and Michelson tested the effectiveness of sending eligible voters short candidate videos using WhatsApp. The experiments, conducted during the 2014 elections in Brazil, found that delivering short videos via WhatsApp is a powerful method of increasing turnout among teen voters. Indeed, the 76.51 percentage point boost in youth voter turnout in Rio and the 44.05 percentage point increase in Santa Catarina reflect an unusually powerful mobilization treatment. The authors highlight the conventional wisdom that personalized GOTV methods are effective, while impersonal methods are less effective, and note how this view is challenged by the Noticeable Reminder Theory which posits that it is not the personal nature of GOTV messaging methods that make these methods effective, but rather the fact that they are noticeable. ${ }^{124}$

Moura and Michelson note that this theory is consistent with the disparate findings of email and Facebook experiments in which emails sent by personal friends or trusted sources and Facebook messages from friends generate relatively large increases in turnout, while email send from other sources and Facebook banner ads are ineffective at boosting turnout. ${ }^{125}$ The authors offer a third possibility, positing that unlike door-to-door canvassing, which will be interpreted as personal by all recipients, messages delivered by text message will be interpreted as personal by younger recipients and as impersonal by older recipients. They further hypothesize that text message reminders to vote will be more effective among younger recipients because they are more likely than older voter to have mobile internet. ${ }^{126}$ As colleges and universities seek to mobilize student voters, they will need to consider which technologies and applications students are using most and adapt their GOTV strategies to increase visibility and student attention.

Text Messaging. Cell phone use, including texting, is pervasive among American youth. To what extent can this technology be harnessed to get out the vote? Research on this question is ongoing. Alisson Dale and Aaron Strauss conducted a nationwide field experiment with over 8,000 voters during the 2006 election. They found that text message reminders produce a statistically significant 3.0 percentage point increase in the likelihood of voting, suggesting that that a noticeable reminder may be sufficient to drive some voters to the polls. ${ }^{127}$ The size of this effect is consistent with other experiments on texting. In their overview of experimental findings regarding the effectiveness of text messaging Green and Gerber (2015) report that mobilizing people by text raises turnout by approximately 2.6 percentage points. ${ }^{128}$

Similar to Dale, Strauss, Moura, and Michelson, Gerber and Green wonder whether the effectiveness of early text messaging experiments might be attributed to the fact that they command voters' attention. Additional studies in San Mateo during low-turnout elections in November 2009 and June 2010 found a small but statistically significant effect of text message reminders. Personalizing the messages by referring to the recipient by name did not enhance the 
effect. ${ }^{129}$ A third study conducted by Rock the Vote during the final days of the 2012 presidential election included more than 180,000 people who had given Rock the Vote their mobile phone numbers when they registered to vote. A group texted the day before Election Day with the message "Tomorrow is election day! Get info. on where to go and what to bring here: URL" and a group that received the preceding message with additional instructions to "reply with your address to find your polling location \& time” turned out at a rate 0.6 percentage points higher than the control group. Further Election Day messaging failed to boost turnout, and sending the Election Day message "Stop what you're doing and GO VOTE NOW!" actually depressed turnout. ${ }^{130}$ On average, receiving any text message from Rock the Vote boosted participation by only 0.5 percentage points, suggesting that the novelty of the technology and the ability to attract voter attention through text messages may have decreased since 2006 when the technology was new. Although the effects may be smaller than in the past, text messaging is still an efficient way to reach young voters.

Three recent experiments by Don Green, David Broockman, Joshua Kalla, and Alan Yan confirmed that texting works to increase voter turnout. The first experiment, conducted with nonwhite voters, voters under 35, and unmarried women during the 2016 presidential election in Arizona, showed an increase of 0.55 percentage points. A conversational message (ending in “Do you plan to vote?”) resulted in 30\% more replies but was no more effective at stimulating turnout. ${ }^{131}$ The second study, conducted with Illinois Democrats under 40 years old during the 2016 general election produced an estimated 0.25 percentage point boost in turnout. The third study, conducted with Democratic-leaning voters under 40 during the 2017 Virginia gubernatorial primary, found that peer-to-peer texting increased turnout by 0.62 percentage points. While making the message more conversational had no effect on turnout, providing polling place information boosted turnout by 0.35 percentage points. ${ }^{132}$ In summary, texting increases turnout among young voters. While the effects are small, the technique is an efficient way to boost turnout. Given the pervasiveness of cell phone use on college campuses, and the average age of students on most campuses, GOTV texts would make a valuable supplement to more high impact campus mobilization practices.

\section{Beyond GOTV Tactics \& Experiments: Creating a Campus Culture of Engagement}

This paper has focused on the relative effectiveness of specific tactics - or modes of contact - for mobilizing voters to cast their ballots. Whether making the campus a polling place or creating a climate in which politics is discussed pervasively across campus all year long, there may be ways to boost turnout rates that have little to do with GOTV outreach to individual students on - or shortly before - Election Day. Next, we briefly consider some of these broader

approaches, many of which can be tested empirically through future research. 


\section{Positioning Polling Places on College Campuses}

Lowering the costs of engaging in a behavior generally increases the probability of people engaging in that behavior. One of the costs associated with voting is traveling to the polling place. Studies predicting voter turnout based on voters' distance from the polling place while controlling for confounding variables, ${ }^{133}$ matching immediate neighbors in different precincts, ${ }^{134}$ and examining exogenous shocks from precinct consolidation ${ }^{135}$ all show that greater distance from polling places are associated with lower voter turnout. That is, people who live closer to polling places vote at higher rates than people who look similar but have to travel further to vote. If this relationship is causal, then moving polling places onto campuses would increase voter turnout among students by making it easier to vote. Colleges and universities could petition local election officials to locate a polling place on their campus, which would be maximally convenient for their students. There are many jurisdictions that create special polling places for large retirement communities where residents would have difficulty traveling to the polling place, so creating polling places on campus would not be without precedent. Some colleges and universities already have been successful in the fight to secure on-campus polling places. ${ }^{136}$ Other campuses could pursue a similar strategy.

\section{Fostering Political Learning and Engagement Year-Round}

While this paper focuses on specific techniques designed to boost student voting rates by registering and mobilizing students before Election Day, many colleges and universities are interested in pursuing a year-round approach to shaping campus culture in ways that promote civic learning and democratic engagement. Nancy Thomas and Margaret Brower introduced a Politics 365 model that argues for "attention to improving the campus environment as a means to increasing the pervasiveness and effectiveness of student development for civic engagement, political activism, and social action." 137 As the name of the model suggests, the model promotes civic learning year-round, rather than efforts that are episodic and tied narrowly to electionseason efforts to mobilize student voters. The Politics 365 model is based on a 2013-2014 case study of five colleges and universities with voter turnout rates between 5 and 20 percentage point higher than predicted ("positive outliers") as well as two campuses with voting rates seven percentage points (or more) lower than predicted ("negative outliers”). The goal of the project was to identify common attributes that foster political learning and engagement.

The researchers identified five attributes of positive outlier campuses: social cohesion, diversity as a realized practice, shared responsibility, support for political action, and pervasive political discussions. Positive outlier campuses are characterized by strong interpersonal relationships between faculty and students, an institutional concern for student well-being, peerto-peer support, and community support. They exhibit compositional diversity in the student population coupled with a strong commitment on the part of the institution to promote social mobility and equal opportunity. The campuses share power and responsibility with students, treating students as valued colleagues with real decision-making authority. Campus leaders show support for political action, both during and between elections. Moreover, the campuses are a place where students, faculty, and staff exchange a diversity of perspectives, especially around policy questions and political issues. ${ }^{138}$ 
In August 2018 the IDHE released a new report entitled "Election Imperatives: Ten Recommendations to Increase College Student Voting and Improve Political Learning and Engagement in Democracy” that provides ten recommendations for what campuses can do to foster a culture of political learning and engagement. ${ }^{139}$ The authors encourage campuses to: reflect on past elections and reimagine 2018, remove barriers to student voting, develop informed voters, establish a permanent and inclusive coalition to improve the climate for learning and participation, invest in the right kind of training, talk politics across campus, involve faculty across disciplines in elections, increase and improve classroom issue discussions across disciplines, support student activism and leadership, and empower students to create a buzz around the election. Advice and resources are provided to help campuses follow each of these recommendations. ${ }^{140}$ Ideally, best practices advice developed based on case studies of successful campuses will be used to form hypotheses for future field experiments designed to measure the effectiveness and generalizability of the findings regarding specific approaches to boosting political engagement, including voter turnout, among college students.

The focus on fostering a campus "culture of engagement" that makes students think of themselves as voters and engaged citizens fits well with the common theme discovered through a review of the experimental GOTV literature. A key "takeaway” point from the experimental literature is that the decision to vote is strongly shaped by one's social environment. ${ }^{141}$ Making voting more convenient, supplying voters with information, and reminding them about an upcoming election produces small effects compared to providing social inducements to vote by triggering a voter's sense of civic duty or identity or a sense that their community expects them to vote. ${ }^{142}$

\section{Conclusion and Directions for Future Research}

Most of the results from the well-established voter mobilization literature seem to carry over to the college campus setting. However, broad lessons need to be adapted to the specific circumstances of college campuses. ${ }^{143}$ The most salient differences between college campuses and the broader electorate are:

1) The target population is much younger and has little history of voting.

2) The target population is highly mobile and moves more frequently than other voters.

3) The target population is enmeshed in dense social networks (e.g., other students and student organizations), interaction with bureaucracy on a regular basis (e.g., registering for classes and paying fees), and collectively interact several times a week in classes.

4) Universities have a wide range of methods of contacting targets (e.g., email, phone, mailing address).

5) The target population is very plugged into the Internet and often difficult to reach in person.

While the relative inexperience with the act of voting and high degree of mobility make engaging college students challenging, the other features of college campuses open a wide range 
of possibilities for voter mobilization. Below are tactics that we would like to see rigorously studied:

a) Voter registration at matriculation and class enrollment. Prior experiments have shown that voter registration is a hurdle to participation. Interventions to increase voter registration are either time intensive (e.g., classroom presentations) or rely on possibly disinterested students to complete (e.g., emailing registration forms). Making voter registration part of the matriculation and class enrollment process would remove this hurdle during a period when students are already filling out forms. Voter registration at student orientations and move-in days present additional opportunities to capture student attention when they are already filling out paperwork.

b) Campus-wide competitions. In general, contests cause people to put more effort into an activity than they would otherwise. The idea of hosting competitions across dormitories, classes, clubs, and other campus units is very sensible. Such competition can leverage social networks, capitalize on volunteer enthusiasm, and generate "buzz" to engage sections of the campus community who are otherwise unmoved by centralized coaxing vote. Even if we think such competitions are generally effective, how best to structure the competitions to increase voter turnout is unclear. ${ }^{144}$ Randomly assigning competition structures and incentives across a large number of campuses could help colleges understand how best to use competitions to spur electoral participation.

c) Election rallies and events. Holding one exciting event that attracts a large number of students is probably cheaper than traditional modes of voter outreach where students need to be contacted individually. Such events also have the virtue of placing people attending for the spectacle in social proximity with people committed to voting. The crowd can then reinforce the social norm that voting is an important duty that college students should engage in. Providing funds for randomly selected universities to host electionrelated educational events, parties, rallies, and candidate debates, would help answer this question. $^{145}$

d) Using student volunteer social networks to increase voter turnout. Campuses are full of civic-minded students who volunteer for activities. These individuals are obviously not the norm (otherwise this review would not be necessary), but they typically operate in social circles that include students less electorally engaged. By recruiting a large number of volunteers from different corners of campus social life (e.g., shoot for diversity of class year, major, ethnicity, gender, work schedule), it is likely that most of the campus population is two degrees of separation from these volunteers. These initial volunteers can recruit friends to upload their contacts (e.g., email, phone, Instagram, Snapchat, Facebook, twitter) and then to encourage randomly selected individuals to vote with direct personal messages. The program would require effort to recruit, train, and coordinate the initial volunteers, ${ }^{146}$ but the program is inherently scalable and can encompass the entire campus.

e) Making electoral participation part of the campus identity. Campuses have distinct cultures and administrators can make choices to shape that culture through admissions, 
rules, and programs. There is obviously a limit to how much administrators can shape campus culture, but there are concrete steps that administrators can take to make voter turnout an expectation. For instance, voter turnout could be part of the student code of conduct, discussed during matriculation events, and subject to frequent campus announcements around elections much like concerns about parking or under-age drinking are discussed. If administrators believe that the civic health of their campus is important, then they should emphasize the importance of voting at appropriate times.

f) Integrate civic engagement into the curriculum. Classroom material is often siloed off from activities in the broader world. However, small changes could be made to parts of the curriculum to ensure that all students are exposed to the basics of the voting process. First year seminars could spend time walking students through the mechanics of voting. Classes could not only register students to vote, but could also partner with groups like the League of Women Voters to distribute non-partisan voter guides. The application of classroom work to our political environment could be actively encouraged rather than discouraged. The goal would not be to hijack courses or interfere with academic freedom in the classroom, but to foster an environment where civic participation is viewed as part of the college experience. ${ }^{147}$

These engagement ideas could be studied within campuses by randomizing the application of the mobilization technique across individuals, dorms, or classrooms. They could also be studied across universities given a sufficiently large set of participating institutions. ${ }^{148}$ The key to understanding which of these tactics is effective, and for what types of students, is to secure institutional buy in. The data and analysis required is not onerous. Given the vast quantity of research that occurs on college campuses and the concern universities show about the holistic well-being of their students, it is surprising that more research has not been done on how best to engage students in the electoral process. Our hope is that this dynamic changes in the coming years and universities are viewed as viable laboratories of democracy. 


\section{Appendix A: Sample of Students Learn Students Vote Coalition Partners}

Over 300 groups belong to the Coalition, these were listed on the website as of August 2018.

1. American Association of College and Universities (AAC\&U)

2. AASCU's American Democracy Project

3. Association of big Ten Students

4. Association of Young Americans,

5. Alliance for Youth Organizing (AYO)

6. ALL IN Campus Democracy Challenge

7. The Andrew Goodman Foundation

8. the Annette Strauss Institution for Civic Life

9. Asian and Pacific Islander American Vote (APIAVote)

10. APIA Vote-Michigan

11. Ballot Ready

12. \#Baltimore Votes

13. Black University

14. Black Youth Vote!

15. Brennan Center for Justice

16. CALPIRG Education Fund

17. Campus Election Engagement Project (CEEP)

18. Campus Vote Project

19. Center for American Politics a\& Citizenship (CAPC)

20. The Center for Civic Justice at Stony Brook University

21. CIRCLE

22. Civic Nation

23. CivicTN

24. Common Cause Illinois

25. Common Cause North Carolina

26. ConPIRG

27. CoPIRG

28. CUSP

29. The Democracy Commitment (TDC)

30. Democracy Matters

31. Democracy Works

32. Election Protection coalition

33. Engage Miami
34. Equality Pennsylvania

35. Fair Elections Legal Network (FELN)

36. Feminist Majority Foundation

37. Forward Montana Foundation

38. Foundation for California Community Colleges

39. Generation Progress

40. Georgia Shift

41. GU Votes

42. icitizen

43. ideas42

44. Inspire

45. U.S., Lawyers' Committee for Civil Rights Under Law

46. LeadMN

47. MASSPIRG

48. Mi Familia Vota

49. Mile 22 Associates

50. MontPIRG

51. motivate

52. MPIRG

53. NAPSA Lead Initiative,

54. National Association For Equal Opportunity in Higher Education (NAFEO)

55. National Civic Leadership Council (NCLC)

56. NCPIRG Education Fund

57. The Nebraska Civic Engagement Table

58. New Era Colorado

59. The New York State Civic Engagement Table (NYCET)

60. NJPIRG

61. NUvotes

62. OpenMind,

63. Oregon Student Association

64. People's Action

65. Piedmont Virginia Community College (PVCC) 
66. Planned Parenthood Generation Action Network

67. Project Pericles

68. Rock the Vote

69. Roosevelt Institute

70. Santa Fe College

71. Scholars Strategy Network

72. Southern Conference Votes

73. State Voices

74. New Voters Project

75. Secular Student Alliance

76. Text, Talk, Vote

77. United States Student Association

78. U.S. PIRG Education Fund
79. Virginia21

80. The Virginia Civic Engagement Table

81. VoteRiders

82. Vote16USE

83. Voto Latino

84. Walk 2 Vote

85. The Washington Bus

86. he Washington Student Association

87. Western Native Voice

88. Youth Engagement Fund

89. Young Invincibles

90. Young People For (YP4)

91. CollegeQorps. 


\section{Appendix B: Civic Education and College Student Political Engagement}

Although institutions of higher education are becoming increasingly outspoken about their desire to mobilize student voters, their primary mission is broader than getting out the vote. Colleges and universities seek to educate students in ways that prepare them to become lifelong learners who make productive contributions in the workplace and in their communities. Increasingly, campuses are being called upon to be more intentional in their efforts to promote civic learning across all disciplines. ${ }^{149}$

To what extent does civic education boost voter turnout? Some research has suggested that mandatory civics classes do not boost political engagement, ${ }^{150}$ while other studies suggest that for courses to boost participation, teachers must move beyond teaching to a test to engage students in meaningful political discussions regarding real world problems. ${ }^{151}$ While education level is correlated with voter turnout, it can be difficult to determine the mechanisms connecting education and civic engagement. ${ }^{152}$ David Campbell's analysis of civic education data collected in 1999 finds that an open classroom climate has a positive impact on adolescents' civic knowledge and appreciation of political conflict, even when controlling for numerous individual, classroom, school, and district characteristics. Furthermore, an open classroom environment increases young people's stated intention to be an informed voter. ${ }^{153}$ Campbell's findings are consistent with the findings of scholars across the U.S. and Europe including the findings of Diana Owen whose research on junior and senior high civic learning experiences suggests that high quality civic education, including an open classroom environment and active learning opportunities, promote long-term civic and political engagement. ${ }^{154}$ Scholars have developed books, book chapters, and teacher guides for improving the quality of classroom deliberation. ${ }^{155}$ Others have documented the (K-12) campus climate required to facilitate civic learning and engagement. ${ }^{156}$

Research by Elizabeth Beaumont and her colleagues with the Carnegie Foundation's Political Engagement Project (PEP) provides empirical evidence that well-designed, well-taught college courses can develop the knowledge, skills, and motivations required for civic action. Beaumont concludes that such education promotes informed and active political involvement without changing students' ideological views and notes that taking such courses can close the "democratic achievement gap" between students who entered the classroom with different levels of political interest and engagement. ${ }^{157}$ Nancy Thomas and Margaret Brower (2017) suggest that best practices include integrating political learning into the classroom through discussions on controversial social and political issues among students with diverse social identities, ideological perspectives, and lived experiences. ${ }^{158}$ While each of these studies is valuable in furthering our understanding of the link between civic education and political engagement, a review of this literature reveals that most findings are based on qualitative case studies, self-selection, or students' self-reported survey data regarding their current and future political behavior. ${ }^{159}$ Two exceptions that utilize random assignment include a study of high school students enrolled in the Democracy Prep charter schools ${ }^{160}$ and a study of college students enrolled in introductory U.S. politics courses. ${ }^{161}$ Additional research is needed to test the effectiveness of specific pedagogical interventions both inside and outside of the classroom. Specific interventions can be designed to promote civic knowledge, skills, and identity in classrooms and student organizations. Various 
approaches to civic learning to boost student electoral engagement can be developed, randomized, and assessed through consortiums of researchers who share a normative and empirical interest in student mobilization. ${ }^{162}$

\section{Notes}

${ }^{1}$ Richard Fry. "Younger generations make up a majority of the electorate but may not be a majority of voters this November,” Pew Research Center, June 12, 2018.

${ }^{2}$ Ibid.

${ }^{3}$ Alan S. Gerber, Donald P. Green, and Ron Shachar. "Voting May Be Habit-Forming: Evidence from a Randomized Field Experiment,” American Journal of Political Science vol. 47 (2003): 540-550.

${ }^{4}$ Martin P. Wattenberg, Is Voting for Young People? 4 ${ }^{\text {th }}$ Edition. (New York: Routlege, 2016).

${ }^{5}$ Michael Dimock. “Defining generations: where Millennials end and post-Millennials begin,” Pew Research Center, March 1, 2018.

${ }^{6}$ Ibid.

${ }^{7}$ Anne Colby, Elizabeth Beaumont, Thomas Ehrlich, and Josh Corngold, Educating for Democracy: Preparing Undergraduates for Responsible Political Engagement (The Carnegie Foundation for the Advancement of Teaching, 2017).

${ }^{8}$ The National Taskforce on Civic Learning and Engagement, "A Crucible Moment: College Learning \& Democracy’s Future,” (https://www.aacu.org/sites/default/files/files/crucible/Crucible_508F.pdf).

9 Pew Research Center, “The Generation Gap in American Politics,” March 1, 2018.

${ }^{10}$ Ibid.

${ }^{11}$ Drew Desilver. “U.S. trails most developed countries in voter turnout,” Pew Research Center, May 21, 2018.

${ }^{12}$ Northwestern University's record-setting voter registration program raised students' turnout - which was a typical 49 percent in 2012 - to 64 percent in 2016, well above the 58 percent national average for citizens of all ages. For more details see Michael Peshkin, "Cracking the Puzzle of Bringing Out the Youth Vote,” Inside Higher Ed, July 23, 2018.

${ }^{13}$ Donald P. Green and Alan S. Gerber, Get Out the Vote: How to Increase Voter Turnout, $3^{\text {rd }}$ edition, (Brookings Institution Press, 2015).

${ }^{14}$ For more information see Green and Gerber, Get Out the Vote.

${ }^{15}$ For a comprehensive review of voter mobilization field experiments taking place from 1998-2014 see Green and Gerber, Get Out the Vote. The authors use a three-star rating system in which findings marked 
with three stars are based on experiments involving large number of voters using tactics tested by different groups in multiple sites. Two-star rated findings are based on just one or two experiments and require additional replication across different demographic groups and political conditions. One-star ratings indicate that the findings are suggested by experimental evidence, but subject to uncertainty. The conclusion may rest on a single study, or the evidence across studies may be contradictory.

${ }^{16}$ The conference started as an ADP national conference in 2004, The Democracy Commitment (TDC) was added in 2012, and NASPA, after holding its own CLDE annual meeting starting in 2013, merged with the ADP and TDC in 2015. In 2018, after renting space in the AASCU building, TDC found a new home with Campus Compact as the TDC leader, Verdis Robinson, because Campus Compact's Director of Community College Engagement. The 2019 CLDE meeting was, therefore, jointly sponsored by NASPA and the AASCU, while Campus Compact scheduled its own state and national meetings.

${ }^{17}$ For more information go to idhe.tufts.edu.

${ }^{18}$ For more information go to allinchallenge.org.

${ }^{19}$ Free electronic copies of both Teaching Civic Engagement books are available at apsanet.org/teachingcivicengagement.

${ }^{20}$ Only one randomized field experiment is included in the two volumes published by the American Political Science Association. See Elizabeth A. Bennion and David W. Nickerson, "Documenting the Success of Classroom-Based Voter Registration Efforts: Classroom Presentations Trump Technology,” in Teaching Civic Engagement: From Student to Active Citizen (2013), edited by Alison Rios Millett McCartney, Elizabeth A. Bennion, and Dick Simpson.

${ }^{21}$ These experiments are explained later in this paper. See "Evidence from College Campuses: E-mail is Ineffective at Registering New Voters" for details regarding these experiments.

${ }^{22}$ Coalition partners and mission statements are listed at studentslearnstudentvote.org. The names of sample member organizations are listed in Appendix A.

${ }^{23}$ See, for example, “Cracking the Puzzle of Bringing Out the Youth Vote,” Inside Higher Ed, July 23, 2018. Also see Nancy Thomas and Margaret Brower, "Politics 365: Fostering Campus Climates for Student Political Learning and Engagement,” in Teaching Civic Engagement Across the Disciplines, edited by Elizabeth C. Matto, Alison Rios Millett McCartney, Elizabeth A. Bennion, and Dick Simpson.

${ }^{24}$ Benjamin Highton and Raymond E. Wolfinger, "Estimating the effects of the National Voter Registration Act of 1993," Political Behavior, vol. 20 (1998):79-104. Stephen Knack, "Does 'Motor Voter’ Work? Evidence from State-Level Data." Journal of Politics vol. 57 (1995): 796-811. Glenn E. Mitchell and Christopher Wlezien. "The impact of Legal Constraints on Voter Registration, Turnout, and the Composition of the American Electorate," Political Behavior vol. 17 (1995): 179-202.

${ }^{25}$ Michael D. Martinez and David Hill, “Did Motor Voter Work?” American Politics Quarterly vol. 27 (1999): 296-315. Curtis B. Gans, “A Rejoinder to Piven and Cloward.” PS: Political Science and Politics vol. 23 (1990): 175-178.

${ }^{26}$ Stephen Ansolabehere and David M. Konisky, "The Introduction of Voter Registration and Its Effect on Turnout," Political Analysis 14 (2006): 83-100.

${ }^{27}$ For more information about the NSLVE study go to idhe.tufts.edu. 
${ }^{28}$ For a large cache of data and reports regarding pre-college youth registration and voting behavior go to CIRCLE's website at civicyouth.org.

${ }^{29}$ The Young Invincibles hosted a Campus Takeover of National Voter Registration Day on September 25, 2018. Hundreds of campuses hosted events to educate students and help register them to vote. The group encourages campuses to adopt high impact practices such as integrating voter registration into their campus orientation process. Campus grants are also available. To learn more go to younginvicibles.org.

${ }^{30}$ Elizabeth A. Bennion and David W. Nickerson, "I Will Register and Vote if You Show Me How: A Field Experiment Testing Voter Registration in College Classrooms,” PS Political Science \& Politics vol. 49 (2016): 867-871.

31 Ibid.

${ }^{32}$ For a more in-depth description of how to conduct the experiment on a single campus see Elizabeth A. Bennion, "I'll Register to Vote If You Teach Me How: Results of a Classroom-Based Field Experiment," Indiana Journal of Political Science vol. 11 (2009): 20-27. For complete details regarding the national field experiment, see Bennion and Nickerson (2016), "I Will Register and Vote if You Show Me How.”

${ }^{33}$ Both faculty and student presenters should receive detailed instructions and assistance in meeting legal requirements. A voter registration coordinator must enforce a strict protocol for collecting completed registration forms from all presenters and submitting these forms to voter registration officials.

${ }^{34}$ The Higher Education Amendments of 1998 added a new provision to the Program Participation Agreements that requires institutions to make a good faith effort to distribute voter registration forms to each student in attendance. This law does not apply in states without a voter registration requirement, or if the voter can register at the time of voting. The institution requests and receives the forms from the state and must make the forms "widely available" to each student enrolled in a degree or certificate program and physically in attendance at the institution. According to H.R. Conf. Rep. No. 105-750, "[t]he process for distributing forms should be designed to ensure that each student . . . is offered the form or the opportunity to receive a form from the institution. This may include, but is not limited to, providing a phone prompt when the student registers via telephone or a similar prompt during registration that is carried out via the internet or by facsimile." The institution must request the forms from the state 120 days prior to the deadline for registering to vote. If the state does not send sufficient forms to the institution within 60 days prior to the voter registration deadline, the institution is not liable for failure to comply with the law for that election year. Later, the Higher Ed Amendments of 2008 added the following text to the Voter Registration Act effective August 14, 2008: "The institution shall be considered in compliance with the requirements of subparagraph (A) for each student to whom the institution electronically transmits a message containing a voter registration form acceptable for use in the State in which the institution is located, or an Internet address where such a form can be downloaded, if such information is in an electronic message devoted exclusively to voter registration.”

${ }^{35}$ Elizabeth A. Bennion and David W. Nickerson, “The Cost of Convenience: An Experiment Showing E-Mail Outreach Decreases Voter Registration” Political Research Quarterly vol. 42 (2011): 858-869.

${ }^{36}$ Elizabeth A. Bennion and David W. Nickerson, “Online Registration and Email Outreach to Boost Electoral Participation," paper presented at the Annual Meeting of the American Political Science Association, Boston, August 31, 2018. 
${ }^{37}$ Chris Kennedy and Michelle Mayorga, “Text Message Experiments in 2008,” a presentation made at the Analyst Institute, 2009.

${ }^{38}$ David W. Nickerson, “Do Voter Registration Drives Increase Participation? For Whom and When?” The Journal of Politics vol. 77 (2015): 88-101.

${ }^{39}$ Streets included for each city included both poor and wealthy streets, while the very wealthiest and poorest streets were excluded from the experiment. While the increase in registration was largest on relatively poor streets, this gap is counterbalanced by higher turnout among new registrants living on wealthier streets. Taken together, the results of these six experiments suggest that electoral reforms reducing the costs associated with voter registration may boost registration and turnout rates, but may not alter the overall composition of the electorate.

${ }^{40}$ Green and Gerber, Get Out the Vote, but note that the translation of registrations into votes was highly variable across elections and registrant socioeconomic status. See endnote 39, above.

${ }^{41}$ Michael Peshkin, "Cracking the Puzzle of Bringing Out the Youth Vote,” Inside Higher Education, July 23, 2018.

${ }^{42}$ See Kim Castle, Janice Levy and Michael Peshkin, CIRCLE Working Paper \#66, "Local and Absentee Voter Registration Drives on a College Campus,” October 2009, available at civicyouth.org.

${ }^{43}$ For a video of Northwestern's program in action see tinyurl.com/100percentVR.

${ }^{44}$ Peshkin, "Cracking the Puzzle of Bringing Out the Youth Vote.”

${ }^{45}$ Results are based on the NSLVE study conducted by the Institute for Democracy \& Higher Education at Tufts University.

${ }^{46}$ Laura Bennett, Rebecca Kaplan, Patrick Moran, and Lindsay Robinson, "Best Practices to Facilitate Out-of-State Student Voting in North Carolina,” North Carolina Common Cause, 2014.

${ }^{47}$ Green and Gerber (2015) report that door-to-door canvassing increased turnout in 44 out of 51 the experiments covered in their book.

${ }^{48}$ See Green and Gerber, Get Out the Vote.

${ }^{49}$ David W. Nickerson, "Hunting the Elusive Young Voter,” Journal of Political Marketing vol. 5 (2006): 47-69.

${ }^{50}$ Green and Gerber (2015) report that, on average, 15 contacts are required to produce one vote among people with whose likelihood of voting is between $30 \%$ and $50 \%$ without any contact from canvassers. By comparison, 22 contacts are required to produce one vote for people with less than a $30 \%$ likelihood of voting on their own. Yet an even greater number of contacts is required if the population you are targeting is already likely very likely to vote ( $>50 \%$ or above).

51 See, for example, Arceneaux and Nickerson's analysis of 11 randomized face-to-face voter mobilization field experiments in which they conclude that face-to-face mobilization is better at stimulating turnout among low-propensity voters in prominent elections than in lower salience elections. Kevin Arceneaux and David W. Nickerson, "Who Is Mobilized to Vote? A Re-Analysis of 11 Field Experiments.” American Journal of Political Science vol. 53 (January 2009): 1-16. 
${ }^{52}$ Green and Gerber, Get Out the Vote.

${ }^{53}$ Ibid.

${ }^{54}$ For example, see Melissa R. Michelson, "Mobilizing the Latino Youth Vote: Some Experimental Results,” Social Science Quarterly vol. 87 (2006): 1188-1206.

${ }^{55}$ Ibid.

${ }^{56}$ David W. Nickerson, “Is Voting Contagious? Evidence from Two Field Experiments,” American Political Science Review, Vol. 102 (2009): 49-57.

${ }^{57}$ Green and Gerber, Get Out the Vote.

${ }^{58}$ This result is not statistically significant. Green and Gerber (2015) report that there is an eleven percent chance that we would observe an estimated effect this large even if the leaflets produced zero new voters.

${ }^{59}$ Green and Gerber, Get Out the Vote.

${ }^{60}$ Ibid.

${ }^{61}$ Jared Barton, Marco Castillo, and Ragan Petrie, "What Persuades Voters? A Field Experiment on Political Campaigning,” Economic Journal, vol. 124 (2014): 293-326. Melissa R. Michelson and others, "The Effect of Prepaid Postage on Voter Turnout: A Cautionary Tale for Election Administrators," Election Law Journal, vol. 11 (2012): 279-90. Donald P. Green and Morris Levy, "The Effects of Voter ID Notification on Voter Turnout: Results from a Large-Scale Field Experiment,” Election Law Journal, vol. 13 (2014): 228-42.

${ }^{62}$ Donald P. Green and others, “The Effects of Lawn Signs on Vote Outcomes: Results from Three Randomized Field Experiments,” paper presented at the Annual Meeting of the Midwest Political Science Association, Chicago, April 4, 2014.

${ }^{63}$ Ibid.

${ }^{64}$ Costas Panagopoulos, "Street Fight: The Impact of a Street Sign Campaign on Voter Turnout," Electoral Studies, vol. 28 (2009): 309-13.

${ }^{65}$ By pooling results over four experiments, Donald Green and his colleagues found that yard signs have a modest effect on advertising candidates' vote shares. They estimate that the effect is probably greater than zero, but unlikely to be large enough to alter the outcome of a contest that would otherwise be decided by more than a few percentage points. For more information see Donald P. Green and others, The Effects of Lawn Signs on Vote Outcomes: Results from Four Randomized Field Experiments,” Electoral Studies 41 (2016): 143-150.

${ }^{66}$ See Panagopoulos, “Street Fight,” and see Green and Gerber, Get Out the Vote.

${ }^{67}$ Adria Lawrence and Bethany Albertson, "How Does Television Change Us? An Analysis of Three Field Experiments," paper presented at the Annual Meeting of the American Association of Public Opinion Research, May 12-15, 2005. 
${ }^{68}$ Mullainathan Sendhil, Ebonya Washington, and Julia Azari. “The Impact of Electoral Debate on Public Opinions: An Experimental Investigation of the 2015 New York City Mayoral Election,” in Political Representation, edited by Ian Shapiro and others (Cambridge University Press 2009), pp. 32441.

${ }^{69}$ David W. Nickerson, "Results from the Spring 2006 Candidates Gone Wild Experiment," unpublished manuscript (Notre Dame University, Department of Political Science, 2007).

${ }^{70}$ Nickerson reports that $17 \%$ of the control group turned out compared to $31 \%$ of the treatment group.

${ }^{71}$ Anecdotally, one of the authors of this paper regularly hosts candidate forums and debates for local, state, and national political races and notes that the number of students who attend such live candidate forums is remarkably low (seldom exceeding 5-10 percent of the audience total) even when the debates are hosted on college campuses. In contrast, debate watch parties (for high profile races) attract a mostly student audience, especially when hosted in the community building of the campus housing complex and serving free pizza, pop, and snacks. Reaching non-residential students remains a challenge.

${ }^{72}$ Elizabeth M. Addonizio, Donald P. Green, and James M. Glaser, "Putting the Party Back into Politics: An Experiment Testing Whether Election Day Festivals Increase Voter Turnout,” PS: Political Science \& Politics, vol. 40 (2007), 721-27.

${ }^{73}$ Green and Gerber, Get Out the Vote.

${ }^{74}$ The probability of obtaining an estimate as large as 3.8 percentage points merely by chance is about one-in-fifty.

${ }^{75}$ Green and McClellan estimate an average cost of \$34 per vote, similar to the estimate of \$35 per vote reported by Addonizio et al. (2007) and competitive with other voter mobilization tactics such as phone calls or direct mail (see Green and Gerber, Get Out the Vote).

${ }^{76}$ Not all festivals have proven equally effective at mobilizing voters. See, for example, Donald P. Green and Oliver A. McClellean, "The Effects of Election Festivals on Voter Turnout: A Field Experiment Conducted During the 2017 General Election, November 2018 (forthcoming).

${ }^{77}$ Donald P. Green and Oliver A. McClellan, The Effects of (Group Name Withheld) Election Festivals on Voter Turnout: A Field Experiment Conducted during a Presidential Election - November 2018 (forthcoming).

${ }^{78}$ Indiana University South Bend's American Democracy Project hosted such an event during the fall 2018 midterm election. Support for such initiatives is available through the Indiana Campus Compact's Campus Electoral Engagement Project (CEEP) grants, and through the SLSV \#votetogether initiative.

${ }^{79}$ Many campuses use TurboVote to register students to vote, leaving the responsibility of handling registration guidelines, absentee ballots, and GOTV text reminders to TurboVote. Consider, for example, the ND Votes program at the University of Notre Dame. More research is needed to test the effectiveness of this approach. 
${ }^{80}$ Campuses have dedicated space and a wide variety of accessible resources including the Office of Student Life, professional IT support, already-purchased furniture and AV equipment with support services, and a combination of faculty, staff, and student leaders with experience organizing campus events.

${ }^{81}$ Farah Stockman, “How College Campuses Are Trying to Tap Students’ Voting Power,” New York Times, March 3, 2018.

${ }^{82}$ Ibid.

${ }^{83}$ ALL IN announces "best in class" award winners, selecting an overall winner in the categories of "highest voting rate" and "most improved voting rate" as well as similar awards divided by institution type (public 4-year, private 4-year, and 2-year) and by institution size (small, medium, or large). Finally, they award select individual "champion" award winners (including a standout faculty member, stand out administrator, standout students, and standout partner).

${ }^{84}$ Farah Stockman, “How College Campuses Are Trying to Tap Students’ Voting Power.”

${ }^{85}$ Welcome to the Big Ten Voting Challenge, a letter to students by University of Michigan President Mark Schlissel, accessed online at https://president.umich.edu/news-communications/letters-to-thecommunity/welcome-to-the-big-ten-voting-challenge/.

${ }^{86}$ Stockman, “How College Campuses are Trying to Tap Students’ Voting Power.”

${ }^{87}$ Of course, there are limitations to this type of data. For example, turnout varies from one presidential race to the next and from one midterm to the next raising the possibility that factors other than campus GOTV activities increased or decreased student participation. The fact that the NSLVE has so many participants is useful in comparing voting rates over time, but also in comparing turnout rates in a given election with those of peer institutions.

${ }^{88}$ Elizabeth M. Addonizio, “The Fourth of July Vote: A Social Approach to Voter Mobilization and Election Day,” Ph.D. Dissertation, Department of Political Science, Yale University, 2011.

${ }^{89}$ For a review of this literature see Green and Gerber, Get Out the Vote.

${ }^{90}$ Green and Gerber, Get Out the Vote.

${ }^{91}$ Ibid.

92 Ibid.

${ }^{93}$ Alan S. Gerber, Donald P. Green, and Christopher W. Larimer, "Social Pressure and Voter Turnout: Evidence from a Large-Scale Field Experiment,” American Political Science Review, vol. 102 (2008): 3348. Todd Rogers, Donald P. Green, John Ternovski, and Carolina Ferrerosa Young, "Social Pressure and Voting: A Field Experiment Conducted in a High-Salience Election,” Electoral Studies vol. 46 (2017): 87-100.

${ }^{94}$ Richard E. Matland and Gregg R. Murray, "Mobilization Effect Using Mail: Social Pressure, Descriptive Norms, and Timing,” Political Research Quarterly, vol. 67 (2013): 304-19. Christopher B. Mann, "Is There Backlash to Social Pressure? A Large-Scale Field Experiment on Voter Mobilization," Political Behavior, vol. 32 (2010): 387-407. 
${ }^{95}$ Panagopoulos, Costas. “Thank You for Voting: Gratitude Expression and Voter Mobilization.” The Journal of Politics vol. 73 (2011): 707-717.

${ }^{96}$ Lauren Deschamps Keane and David W. Nickerson, "When Reports Depress Rather Than Inspire: A Field Experiment using Age Cohorts as Reference Groups,” Journal of Political Marketing vol. 14 (2015): 381-90.

${ }^{97}$ For more information about the effectiveness of GOTV phone banks see David W. Nickerson, "Volunteer Phone Calls Can Increase Turnout," American Politics Research vol. 34 (2006): 271-291. Also see David W. Nickerson. 2007. "Quality is Job One: Volunteer and Professional Phone Calls," American Journal of Political Science 51(2): 269-282.

${ }^{98}$ See David W. Nickerson "Quality Is Job One.” Also see Christopher B. Mann and Casey A. Klofstad, “The Role of Call Quality in Voter Mobilization,” Political Behavior vol. 37 (2015): 135-154.

${ }^{99}$ Green and Gerber, Get Out the Vote.

${ }^{100}$ Donald P. Green, Mary C. McGrath, and Peter M. Aronow, "Field Experiments and the Study of Voter Turnout, Journal of Elections, Public Opinion \& Parties vol. 23 (2013): 27-48.

${ }^{101}$ Matland and Murray, “Mobilization Effect Using Mail,” and Christopher Mann "Is There a Backlash to Social Pressure?”

102 Melissa R. Michelson, Lisa García Bedolla, and Margaret A. McConnell. 2009. "Heeding the Call: The Effect of Targeted Two-Round Phone Banks on Voter Turnout.” The Journal of Politics vol. 71 (2009): 1549-1563.

${ }^{103}$ David W. Nickerson and Todd Rogers, "Do You Have a Voting Plan? Implementation Intentions, Voter Turnout, and Organic Plan Making,” Psychological Science vol. 2 (2010): 94-99.

${ }^{104}$ Alan S. Gerber and others, "Do Perceptions of Ballot Secrecy Influence Turnout? Results from a Field Experiment." American Journal of Political Science vol. 57 (2013): 537-551.

${ }^{105}$ See Mauricio Moura and Melissa R. Michelson (2017) for a discussion of the advantages of digital communication. "WhatsApp in Brazil: Mobilizing Voters through Door-to-Door and Personal Messages," Internet Policy Review vol. 6 (2017): 1-18.

${ }^{106}$ Elizabeth A. Bennion and David W. Nickerson, "Online Registration and Email Outreach to Boost Electoral Participation,” paper Presented at the Annual Meeting of the American Political Science Association, Boston, August 31, 2018.

${ }^{107}$ Bennion and Nickerson, "The Cost of Convenience.”

${ }^{108}$ David W. Nickerson, “Does Email Boost Turnout?” Quarterly Journal of Political Science, vol. 2 (2008): 369-79.

${ }^{109}$ Ibid.

${ }^{110}$ David W. Nickerson. “Does Email Boost Turnout?” 
${ }^{111}$ Alissa Stollwerk, "Does Partisan E-mail Affect Voter Turnout? An Examination of Two Field Experiments in New York City," unpublished manuscript (Columbia University, Department of Political Science, 2015).

112 Neil Malhotra, Melissa R. Michelson and Ali Adam Valenzuela, "Emails from Official Sources Can Increase Turnout (Research Note)," Quarterly Journal of Political Science vol. 7 (2012): 321-332.

113 Neither emails from college administrators nor from student leaders increased registration or turnout in a 26 campus randomized field experiment conducted by Bennion and Nickerson in 2006. See Bennion and Nickerson, "The Cost of Convenience."

114 A later study by Bennion and Nickerson conducted as a randomized field experiment involving 130,000 students at 25 colleges and universities found that while linking to the downloadable form did not affect turnout rates, emails linking to the online registration portal increased registration rates by 1.2 percentage points and turnout rates by 0.7 percentage points. See Elizabeth A. Bennion and David W. Nickerson, "Online Registration and Email Outreach to Boost Electoral Participation," a paper presented at the Annual Meeting of the American Political Science Association, Boston, August 31, 2018.

115 Tiffany C. Danenport, "Unsubscribe: New Evidence that E-mail Mobilization Can Be Effective after All; Results from a Randomized Field Experiment Comparing the Effects of Peer-to-Peer and Mass Email Messages on Voter Turnout," unpublished manuscript (Yale University, Institution for Social and Policy Studies, 2007).

${ }^{116}$ Dan Carnevale, “E-Mail is for Old People,” Chronicle of Higher Education, October 6, 2006.

${ }^{117}$ Ibid.

${ }^{118}$ Robert M. Bond and others, “A 61-Million-Person Experiment in Social Influence and Political Mobilization,” Nature, vol. 489 (2012), 295-98.

${ }^{119}$ Green and Gerber, Get Out the Vote.

${ }^{120}$ Facebook user statistics are available online at statista.com.

${ }^{121}$ Kevin Collins, Laura Keane, and Josh Kalla, "Youth Voter Mobilization through Online Advertising: Evidence from Two GOTV Field Experiments," a paper presented at the Annual Meeting of the American Political Science Association, Washington DC, August 30, 2014.

${ }^{122}$ Holly Teresi and Melissa R. Michelson. 2015. "Wired to Mobilize: The Effect of Social Networking Messages on Voter Turnout.” Social Science Journal 52, 2 (June): 195-204.

${ }^{123}$ Katherine Haenshen, Social Pressure on Social Media: Using Facebook Status Updates to Increase Voter Turnout,” Journal of Communication, vol. 66, 4 (2016): 542-563.

${ }^{124}$ See Allison Dale and Aaron Strauss, "Don't Forget to Vote: Text Messages as a Reminder Tool,” American Journal of Political Science, vol. 53-4 (2009): 787-804.

${ }^{125}$ Moura and Michelson, Whatsapp in Brazil, p 4.

${ }^{126}$ Moura and Michelson, Whatsapp in Brazil, p. 5. 
127 Allison Dale and Aaron Stauss, “Don’t forget to Vote,” American Journal of Political Science, vol. 53 (2009): 787-804.

${ }^{128}$ For more experiments testing the effects of texting on voter turnout, see Ryan Friedrichs, "Young Voter Mobilization in 2004: Analysis of Outreach, Persuasion, and Turnout of 18-29 Year-Old Progressive Voters,” unpublished manuscript (Skyline Public Works, 2006). Also see Costas Panagopoulos, “The Impact of SMS Text Messages on Voter Turnout,” unpublished manuscript (Fordham University, Department of Political Science, 2007).

${ }^{129}$ Neil Malhotra and others, "Text Messages as Mobilization Tools: The Conditional Effect of Habitual Voting and Election Salience,” American Politics Research, vol. 39 (2011): 664-81.

${ }^{130}$ Josh Kalla, John Ternovski and Laura Keane, as reported in Green and Gerber, Get Out the Vote.

${ }^{131}$ A Results Memo to One Arizona is available at https://joshuakalla.com/research.html.

${ }^{132}$ A Results Memo addressed to NextGen is available at https://joshuakalla.com/research.html.

133 Joshua J. Dyck and James G. Gimpel. "Distance, Turnout, and the Convenience of Voting," Social Science Quarterly vol. 86 2005): 531-548.

${ }^{134}$ Enrico Cantoni, “A Precinct too Far: Turnout and Voting Costs.” Unpublished manuscript, 2016, available at http://economics.mit.edu/files/11997.

135 John E. McNulty, Conor M. Dowling and Margaret H. Ariotti. "Driving Saints to Sin: How Increasing the Difficulty of Voting Dissuades Even the Most Motivated Voters." Political Analysis vol. 17 (2009):435-455. Also see Henry E. Brady and John E McNulty, "Turning Out to Vote: The Costs of Finding and Getting to the Polling Place" American Political Science Review vol. 105 (2011):115-134.

${ }^{136}$ Prairie View A\&M, Texas’s oldest historically black university, fought to persuade Waller County to allow a polling location on campus and succeeded in September 2013. The voting booth required a decades-long campaign spearheaded by the university's Student Government Association. For more information see Elizabeth Sohns, "College Campus Voting Booths and Their Impact on Millenials," Generation Progress, April 4, 2014.

${ }^{137}$ Nancy Thomas and Margaret Brower, "Politics 365: Fostering Campus Climates for Student Political Learning and Engagement," in Teaching Civic Engagement Across the Disciplines,” edited by Elizabeth Matto, Alison Rios Millet McCartney, Elizabeth A. Bennion and Dick Simpson (American Political Science Association, 2017): 361-374.

138 The notion that college students become more politically engaged if they are repeatedly exposed to political conversations in college is supported by the research of Casey Klofstad, who conducted a tenyear study of residential students at the University of Wisconsin-Madison. Using panel data, Klofstad found that those who were assigned to dorms in 2003 where they were exposed to political discussion by their randomly-assigned roommate became more likely to join civic-minded student organizations such as student government, partisan political organizations, and community volunteer organizations. This effect lasted throughout their four years of college, and a follow-up survey found that study participants who were exposed to political discussion as first-year college students were still more likely to be active civically nearly ten years later. See Casey A. Klofstad, Civic Talk: Peers, Politics, and the Future of 
Democracy (Temple University Press, 2011). Also see Klofstad's research on this subject in American Politics Research (2009), Social Forces (2010), and Political Communication (2015).

139 The IDHE report, authored by Nancy Thomas, Margaret Brower, Ishara Casellas Connors, Adam Gismondi, and Kyle Upchurch, is available online at idhe.tufts.edu.

140 The authors provide detailed description of each recommendation with links to resources for each. The report is also supplemented by the 2018 IDHE Toolkit and a 2018 Partner Resources list. The report includes links to guides on using the NLSVE report, overcoming non-statutory voting barriers, election protection, digital literacy, coalition-building, difficult dialogues, civil discourse, teaching civic learning across the disciplines, supporting student engagement, and developing an action plan. While such guides can be very useful to campuses in planning their own events and activities, it is worth noting that the only GOTV research cited is the single campus classroom voter registration study conducted by Elizabeth Bennion in 2006. Elizabeth A. Bennion, "I'll Register to Vote If You Teach Me How: Results of a Classroom-Based Field Experiment.” Indiana Journal of Political Science vol. 11 (2009): 20-27. More rigorous field experimentation is needed, along with more open-source publication options that allow such reports to link people directly to the best available scientific research.

${ }^{141}$ Green and Gerber, Get Out the Vote.

${ }^{142}$ For a discussion of how civic knowledge, skills, and identity might be developed inside the classroom, see Appendix B.

${ }^{143}$ As Niemi and Hanmer (2010) suggest, college students form their political identities in a "unique social and political environment" which may challenge traditional theories of voter turnout. See Richard G. Niemi and Michael Hanmer, "Voter Turnout Among College Students: New Data and a Rethinking of Traditional Theories,” Social Science Quarterly, vol. 91 (2010): 301-323.

144 The degree to which school pride themed voting competitions permeates the campus culture can be partially tracked through the use of contest related social media hashtags (e.g., \#NDVotes).

${ }^{145}$ Campuses that already host annual debates would be unlikely to stop doing so do participate in a field experiment. However, most campuses do not host local political debates. A funder could recruit campuses to participate by paying some of the costs associated with hosting the events. Schools that agree to participate would be matched into pairs (based on geography and NSLVE data) and then randomly assigned to the control group or treatment group. Another approach is to randomize the student invitation process (as discussed earlier in the paper).

${ }^{146}$ There are even companies with software to help facilitate this process (e.g., https://votercircle.com/).

147 The AAC\&U’s Civic Prompts are one attempt to offer advice for promoting civic education and engagement across the disciplines. The APSA's Teaching Civic Engagement books and the Carnegie Foundation's Educating for Democracy book offer additional case studies of courses that promote civic knowledge and engagement. The development of high quality civic education courses and communitybased learning courses can be supported and encouraged through faculty training sessions and fellowship programs. These courses, in turn, case become laboratories for democracy where cross-campus studies of specific curricula or pedagogical innovations are tested for their effectiveness in producing specific civic outcomes, including voting. See Appendix B for a brief discussion of the role of civic education in boosting political participation.

148 The NSLVE data would be immensely helpful for blocking to reduce unexplained variance. 
${ }^{149}$ National Taskforce on Civic Learning and Democratic Engagement, “A Crucible Moment: College Learning \& Democracy’s Future,” 2012, available at https://www.aacu.org/crucible. Nancy Thomas and others, "Election Imperatives: Ten Recommendations to Increase College Student Voting and Improve Political Learning and Engagement in Democracy,” Institute for Democracy in Higher Education, idhe.org, 2018. Also see Jodi Benenson, Margaret Brower, and Nancy L. Thomas, "Political Citizenship: Whether and Why College Students Vote,” in Why Don't Americans Vote? Causes and Consequences, edited by Bridgett A. King and Kathleen Hale (ABC-CLIO, 2016).

${ }^{150}$ See, for example, Jason Giersch and Christopher Dong, "Required Civics Courses, Civics Exams, and Voter Turnout,” The Social Science Journal, vol. 55 (2018): 160-170.

${ }^{151}$ For a discussion of the importance of curriculum that includes political discussions and hands-on political engagement see Helen Haste, "Citizenship Education: A Critical Look at a Contested Field," in Handbook of Research on Civic Engagement in Youth, edited by Lonnie R. Sherrod, Judith Torney-Purta, and Constance Flanagan (John Wiley and Sons, 2010). While "teaching to the test" seems ineffective at generating long-term engagement, there is some evidence that a state mandated civics exam does, in fact, increase voter registration and turnout (Giersch and Dong, "Required Civics Courses, Civics Exams, and Voter Turnout"). Such mandatory exams have also been found to increase civic knowledge, especially among the children of recent immigrants (David E. Campbell and Richard G. Niemi, "Testing Civics: State-Level Civic Education Requirements and Political Knowledge,” American Political Science Review vol. 110 (2016): 495-511.

152 For a discussion of the difficulty of connecting specific mechanism to engagement levels, see David E. Campell, "Measuring the effects of education on health and civic engagement: Proceedings of the Copenhagen symposium,” March 23, 2006.

153 David E. Campbell, "Voice in the classroom: How an Open Class Climate Fosters Political Engagement among Adolescents,” Political Behavior vol. 30 (2008): 437-454.

154 Diana Owen. “The Influence of Civic Learning on Electoral Engagement and Voting,” in Teaching Civic Engagement: From Student to Active Citizen, edited by Alison Rios Millett McCartney, Elizabeth A. Bennion, and Dick Simpson, (American Political Science Association, 2013).

${ }^{155}$ For guidelines for classroom discussion and deliberation see: Diana E. Hess and Paula McAvoy, The Political Classroom: Evidence and Ethics in Democratic Education (Routledge, 2015). For handbooks on promoting civil discourse and difficult dialogues across campus see the Difficult Dialogues website at difficultdialoguesuaa.org. The Kettering Foundation provides a series of ready-to-use National Issues Forums guides to deliberating about public policy issues. The reports teachers and administrators produced over a decade of using the guides are represented in a book by Stacie Molnar-Main entitled Deliberation in the Classroom: Fostering Critical Thinking, Community, and Citizenship in Schools (Kettering, 2017).

${ }^{156}$ For example, see Sean Healy, "Essential School Supports for Civic Learning,” in Teaching Civic Engagement Across the Disciplines.

157 Elizabeth Beaumont, "Political Learning and Democratic Capacities: Some Challenges and Evidence of Promising Approaches,” in Teaching Civic Engagement: From Student to Active Citizen. For more information see Thomas Erlich, Anne Colby and Elizabeth Beaumont, Educating for Democracy: Preparing Undergrads for Responsible Political Engagement (Jossey-Bass, 2017). 
${ }^{158}$ Nancy Thomas and Margaret Brower, “The Politically Engaged Classroom,” in Teaching Civic Engagement Across the Disciplines. This is a qualitative case study based on observations and interviews with faculty at five campuses where students vote at higher-than-expected levels.

159 This is a common limitation of the political science literature developed as part of the "scholarship of teaching and learning” (SoTL) movement. For a complete review of all civic education and engagement articles published in the Journal of Political Science Education (from 2005-2017) see Elizabeth A. Bennion and Xander E. Laughlin "Best Practices in Civic Education: Lessons from the Journal of Political Science Education,” Journal of Political Science Education vol. 14 (2018): 287-330.

${ }^{160}$ Brian Gill and others, “The Impact of Democracy Prep Public Schools on Civic Participation,” a report by Mathematica Policy Research, April 19, 2018. Democracy Prep is a charter school network that seeks to prepare students for effective citizenship. Researchers matched records from Democracy Prep's admissions lotteries to a national database of registration and voting following the 2016 presidential election. They estimate that Democracy Prep increases voter registration rates by about 16 percentage points and increases turnout rates by about 12 percentage points.

${ }^{161}$ Ryan L. Claassen and J. Quin Monson, "Does Civic Education Matter? The Power of Long-Term Observation and the Experimental Method,” Journal of Political Science Education vol. 11 (2015): 404421.

${ }^{162}$ Elizabeth Bennion and Cherie Strachan founded a Consortium for Inter-Campus SoTL Research to allow teacher-scholars at all institution types to work together to learn more about the most effective ways to promote civic and political participation through education. Their inaugural project, a national survey of student leaders, was designed to unpack the "black box" of student organizational culture and determine whether students are practicing the skills and developing the attitudes most likely to lead to long-term civic identity and engagement. See J. Cherie Strachan and Elizabeth A. Bennion, "Extending Assessment beyond Our Own Programs and Campuses: The National Survey of Student Leaders and the Inter-Campus Consortium for SoTL Research,” PS: Political Science \& Politics vol. 49 (2018): 111-115. 